\title{
COVID-19: The Disease, the Immunological Challenges, the Treatment with Pharmaceuticals and Low-Dose Ionizing Radiation
}

\author{
Jihang Yu ${ }^{1}$, Edouard I. Azzam ${ }^{1}$, Ashok B. Jadhav ${ }^{1}$ and Yi Wang ${ }^{1,2, *}$ \\ 1 Radiobiology and Health, Isotopes, Radiobiology \& Environment Directorate (IRED), Canadian Nuclear \\ Laboratories (CNL), Chalk River, ON K0J 1J0, Canada; jihang.yu@cnl.ca (J.Y.); edouard.azzam@cnl.ca (E.I.A.); \\ ashok.jadhav@cnl.ca (A.B.J.) \\ 2 Department of Biochemistry Microbiology and Immunology, Faculty of Medicine, University of Ottawa, \\ Ottawa, ON K1H 8M5, Canada \\ * Correspondence: yi.wang@cnl.ca; Tel.: +1-613-584-3311 (ext. 42653)
}

check for updates

Citation: Yu, J.; Azzam, E.I.; Jadhav, A.B.; Wang, Y. COVID-19: The Disease, the Immunological Challenges, the Treatment with Pharmaceuticals and Low-Dose Ionizing Radiation. Cells 2021, 10, 2212. https://doi.org/10.3390/ cells10092212

Academic Editors: Serge Candéias and Katalin Lumniczky

Received: 27 July 2021

Accepted: 23 August 2021

Published: 27 August 2021

Publisher's Note: MDPI stays neutral with regard to jurisdictional claims in published maps and institutional affiliations.

Copyright: (c) 2021 by the authors. Licensee MDPI, Basel, Switzerland. This article is an open access article distributed under the terms and conditions of the Creative Commons Attribution (CC BY) license (https:// creativecommons.org/licenses/by/ $4.0 /)$.

\begin{abstract}
The year 2020 will be carved in the history books-with the proliferation of COVID-19 over the globe and with frontline health workers and basic scientists worldwide diligently fighting to alleviate life-threatening symptoms and curb the spread of the disease. Behind the shocking prevalence of death are countless families who lost loved ones. To these families and to humanity as a whole, the tallies are not irrelevant digits, but a motivation to develop effective strategies to save lives. However, at the onset of the pandemic, not many therapeutic choices were available besides supportive oxygen, anti-inflammatory dexamethasone, and antiviral remdesivir. Low-dose radiation (LDR), at a much lower dosage than applied in cancer treatment, re-emerged after a 75-year silence in its use in unresolved pneumonia, as a scientific interest with surprising effects in soothing the cytokine storm and other symptoms in severe COVID-19 patients. Here, we review the epidemiology, symptoms, immunological alterations, mutations, pharmaceuticals, and vaccine development of COVID-19, summarizing the history of X-ray irradiation in non-COVID diseases (especially pneumonia) and the currently registered clinical trials that apply LDR in treating COVID19 patients. We discuss concerns, advantages, and disadvantages of LDR treatment and potential avenues that may provide empirical evidence supporting its potential use in defending against the pandemic.
\end{abstract}

Keywords: COVID-19; SARS-CoV-2; low-dose radiotherapy; X-ray

\section{Introduction}

Humans have been living in a world affected by the novel coronavirus disease (COVID19) for more than a year. Starting from a small group of infections, the highly infectious severe acute respiratory syndrome coronavirus 2 (SARS-CoV-2) viral strain has caused over 213 million reported infections, leading to $\sim 4.46$ million deaths so far [1]. Among the closed cases that had an outcome of either recovery and discharge or death, the case fatality rate is $\sim 2 \%$ [1]. Although it has been argued that social measures have been largely ineffective [2], without the assistance of non-pharmaceutical interventions such as stay-at-home, use of sanitizers (hand washing), early case detection, and face masking, it is unlikely that the size of the outbreak can be mitigated or reduced [3]. Whereas active cases temporally declined in February and June 2021, they have rapidly risen again reaching an even higher record set in late April, and reaching over 744,000 daily new cases as of 19 August 2021 (among infected patients, $0.6 \%$ being in serious conditions) [1].

As an infectious disease, COVID-19 can be transmitted from human to human through respiratory droplets and aerosols created within a short distance, as well as prolonged interaction [4]. The World Health Organization (WHO) presented the "three Cs" as places 
with higher COVID-19 spreading risk: Crowded places with many people nearby, closecontact settings, where close-range conversations take place, and confined/enclosed spaces with poor ventilation [5]. These places include restaurants, bars, fitness facilities, theaters, and museums where people tend to be crowded and less fresh air is available. Thus, social distancing (at least $2 \mathrm{~m}$ apart and less than 30-min of close contact) has been advocated as a measure to reduce cluster transmission [6].

Similar to the seasonal flu, COVID-19 is a viral, respiratory illness. Whereas the flu results from an influenza virus infection, COVID-19 is caused by a new type of coronavirusSARS-CoV-2 [7,8]. SARS-CoV-2 is one of the seven pathogenic coronaviruses that cause human respiratory diseases, which also include SARS-CoV, MERS-CoV (Middle-East respiratory syndrome coronavirus), $\mathrm{HCoV-OC43} \mathrm{(human} \mathrm{coronavirus} \mathrm{OC43),} \mathrm{HCoV-HKU1}$ (human coronavirus HKU1), HCoV-NL63 (human coronavirus NL63), and HCoV-229E (human coronavirus 229E) [9].

\section{Epidemiology of COVID-19}

Although the mortality data of COVID-19 are always compared with those of the flu as both induce severe respiratory symptoms that can lead to death, caution must be exercised when interpreting incidence. The Center for Disease Control (CDC) in the United States of America (USA) estimates the seasonal influenza mortality to be at $\sim 0.1 \%$ over the past years [10]. In contrast to indirect counting as in the case of the flu, the CDC collects each COVID-19-related death report directly. Hence, researchers suggested that a comparison between the weekly deaths due to COVID-19 or the flu could be a more valid method [11]. For example, in the USA, the weekly flu deaths were around 500 in early 2020 and decreased at a later time in the year, whereas the weekly COVID-19 deaths soared to over 16,000 and fluctuated with time (Figure 1) [12]. This fluctuation may result from a shortage of ventilators and limitations associated with the work of health providers.

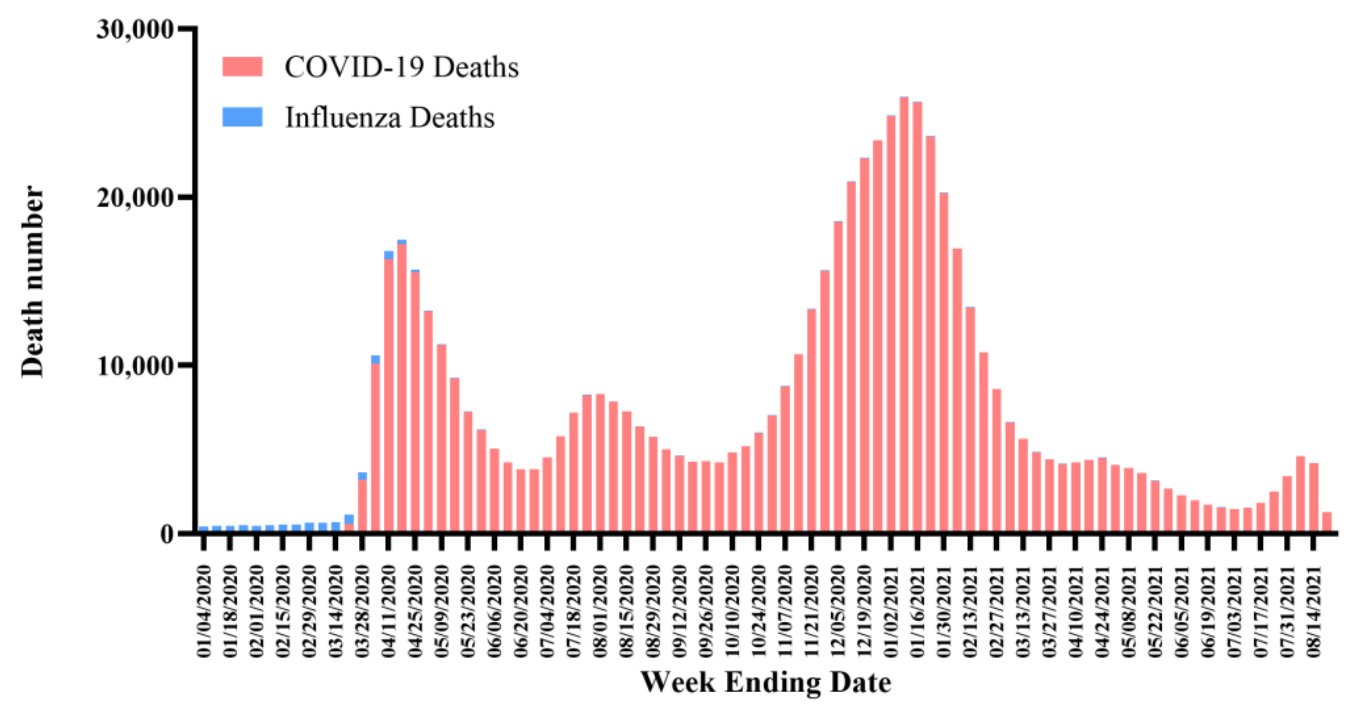

Figure 1. Weekly death analysis of COVID-19 and influenza in the USA. Data may lag by an average of 1-2 weeks, so the trend of decline in recent weeks may not accurately reflect the current situation. Available online: https:/ / data.cdc.gov /NCHS/Provisional-COVID-19-Death-Counts-byWeek-Ending-D/r8kw-7aab (accessed on 24 August 2021).

Several situations complicate the statistics and treatment of COVID-19, including co-infection with SARS-CoV-2 and the common flu virus simultaneously, or infection with SARS-CoV-2 itself rendering existing diseases to deteriorate further and causing death [13]. Although asthma was associated with severe diseases during past influenza epidemics, and respiratory viruses were recognized as cause of acute exacerbations of asthma, scientific analyses did not correlate asthma with a higher severity or mortality in cases of 
COVID-19 [14]. As of early 2021, scientists still could not draw definitive conclusions on the correlation between asthma and COVID-19 outcomes due to various potential bias factors $[15,16]$. However, patients with dermatologic conditions or with gastrointestinal or liver ailments receiving drugs that affect the immune system may have atypical presentations of COVID-19, such as no fever [17-19]. Given the devastating influence of COVID-19 on the lung, chronic obstructive pulmonary disease (COPD) patients may have a higher risk of contracting COVID-19 with severe pneumonia and poor outcomes [20]. Compared to non-COPD patients, hospitalized COPD patients infected with the SARS-CoV-2 virus are 2.6 times more likely to experience admission to the intensive care unit (ICU), invasive mechanical ventilation, or death [21,22]. Although COVID-19 is a growing concern for COPD patients, the latter might be "protected" from severe consequences with appropriate inhaled corticosteroids [21,22]. For COVID-19 patients receiving systemic anticancer therapy, extra caution needs to be taken due to possible treatment-induced immunosuppression [18] It has been considered that patients are at elevated risk of COVID-19-associated complications in scenarios that include diabetes, COPD, cardiovascular diseases, hypertension, malignancies, and infection with the human immunodeficiency virus (HIV). Patients who have received chemotherapy in the last 3 months, extensive radiotherapy, bone marrow or stem cell transplants in the last 6 months, or disruption of their immune system are also at increased risk [23,24].

\section{Symptoms and Transmission of COVID-19}

COVID-19 patients develop symptoms similar to those caused by the common flu, such as fever, cough, fatigue, body aches/muscle pain, headache, sore throat, shortness of breath, nausea, vomiting, or diarrhea [25-27]. One peculiar symptom that distinguishes COVID-19 from the flu is the loss of taste (dysgeusia) or smell (anosmia). Interestingly, this was not recognized as one of the criteria for testing until a significant portion of patients reported anosmia as the primary presenting symptom $[28,29]$. Notably, when a medical researcher who experienced a rapid onset of anosmia did not qualify for COVID-19 assessment, scientists signaled an alarm and persuaded decision-makers to include this symptom as one of the criteria [30].

As the absence or presence of COVID-19 signs and symptoms are not accurate enough for a reliable diagnosis, the standard method of diagnosis is real-time reverse transcriptionpolymerase chain reaction (RT-PCR), one of the most sensitive and accurate laboratory methods to detect viral ribonucleic acid (RNA) [31-34]. Upper respiratory specimens, including nasopharyngeal swab, oropharyngeal swab, nasal mid-turbinate specimen, anterior nares specimen, and saliva specimen, are collected for initial diagnostic testing [35]. In addition, as a traditional fast diagnostic procedure, chest computed tomography (CT) scans have been applied as a complement to RT-PCR for diagnosing COVID-19 due to its high sensitivity [36]. Typical and common CT findings include pulmonary parenchymal ground-glass opacities and consolidation, affecting at least one lobe [37]. In contrast to their sensitivity, the specificity of chest CT scans is relatively low-for instance, the CT findings overlap with signs of other infections, such as influenza, SARS, MERS, and other viral pneumonia [38,39]. Therefore, the CDC and ACR (American College of Radiology) do not recommend chest imaging as a first-line test or routine screening for COVID-19 as it is insufficient for diagnosis [40]. CT scans were recommended only for hospitalized, symptomatic patients with clinical indications for imaging.

The vast majority of COVID-19 patients experience mild or moderate symptomsranging from no symptoms to cold-like symptoms and to mild pneumonia. Some patients may have long-term effects, including neurological [41], cardiac, and respiratory harm [42], as well as mental health problems, and other potential challenges, such as business failure, unemployment, health inequality, social isolation, and even domestic abuse $[43,44]$. Unfortunately, $15 \%$ of COVID-19 patients develop severe symptoms (requiring oxygen) and $5 \%$ present with critical infections (requiring ventilation), and present with breathing difficulties, bluish face or lips, sudden confusion, serious pneumonia, and even respiratory 
failure [45]. In critical cases, patients end up with complications including acute respiratory distress syndrome (ARDS), sepsis, septic shock, and multi-organ failure (heart, kidney), and succumb to death [46-48]. It was also found that the infection was more likely to affect elderly individuals with chronic comorbidities, including hypertension, diabetes, cardiovascular disease, and cerebrovascular disease $[46,49]$.

\subsection{Transmission and Basic Reproduction Number}

The COVID-19 infection transmits easily through coughing, sneezing, singing, talking, and breathing heavily, as long as enough virus particles get into the other person's mouth, nose, or eyes [5]. The incubation period between exposure and symptom onset ranges from 1 to 14 days, with a median time of 5 to 6 days [50]. Significantly, patients can shed the virus even 2 days before showing any symptoms, thus greatly enhancing the infection rate. However, the virus is most transmissible (viral shedding peak) when the RNA level is highest, which coincides with the onset of the symptoms [50].

One of the most discussed terms regarding the transmission capacity of COVID-19 is $\mathrm{R} 0$, or basic reproductive number, a mathematical and epidemiological metric to estimate the transmission potential of an infectious disease [51]. The term $R 0$, pronounced " $R$ naught", originated from demography and ecology studies for calculating the number of offsprings born to one female in her entire life [52]. Epidemiologists then adopted the concept of R0 and defined it as the expected average number or a range of secondary cases in which one case would infect a completely susceptible population [53-56]. In general, if $\mathrm{R} 0$ is greater than $1(\mathrm{R} 0>1)$, then each infected individual causes more than one new infection, indicating an outbreak or epidemic. If $\mathrm{R} 0$ is less than $1(\mathrm{R} 0<1)$, then each infected individual causes less than one new infection, indicating a reduction or dying out of the disease $[51,56,57]$. In the context of COVID-19, R0 values range from 1.3 to 7.7 (which is more variable than the WHO-reported R0 range of 2-4), according to different variables, different methods for modeling, and different estimation procedures [51,58-63]. Specifically, an estimate of the mean R0 for COVID-19 in China for the period of January to April 2020 was 1.58-2.24, whereas the preliminary estimation of the mean R0 in January 2020 was 2.24-3.58, reflecting the possible effectiveness of lockdown and control strategies [62,64,65].

\subsection{Additional Transmission Routes}

Two additional possibilities for COVID-19 transmission attracted attention: Presymptomatic (virus detected before symptom onset) and asymptomatic (virus detected without symptom having developed) transmission [66]. One report claimed that $12.6 \%$ of cases might be transmitted during the pre-symptomatic period [67], and other models suggested that up to half of infections were caused by pre-symptomatic transmission $[66,68]$. Although the feasibility of actual transmission is still unclear [69], pre-symptomatic and asymptomatic transmissions, along with the majority of cases with mild symptoms, might contribute not only to disease sustainability but also to tolerance across populations.

In addition to the pre-symptomatic transmission and asymptomatic transmission, the super-spreading event is another significant and challenging situation. Though a recent study shows that super-spreading may be largely driven by heterogeneity in contact behavior [70], and maybe overestimated due to biases in data collection [70]. Furthermore, patients can get re-infected on separate occasions, which means prior exposure to COVID-19 might not guarantee a hundred percent immunity to the virus whose genome is constantly mutating [71]. This also indicates that when the immune system fails to mount a protective response, viral reinfection, memory antibody levels reduction, and viral nucleic acids persistence could contribute to the second wave of virus replication and another positive test result $[72,73]$.

\section{The Structure and Pathogenesis of SARS-CoV-2}

Coronaviruses are not newly identified pathogens. In 1968, an informal group of virologists recognized a new group of rounded shape viruses under the electron micro- 
scope. They named them coronavirus, recalling the characteristic appearance of the solar corona [74].

The structure of the coronavirus consists of enveloped, spherical, crown-shaped proteins covering the positive-sense, single-stranded RNA (+ssRNA). Its genome size is $30 \mathrm{~kb}$, classifying it as the largest of all RNA viruses [75]. It is thought that bats were the source of the initial coronavirus infections in humans and animals by potential crossspecies transmission and spread [76]. Similar to other coronaviruses, the structural proteins of SARS-CoV-2 consist of a membrane (M) glycoprotein, an envelop (E) protein, a nucleocapsid (N) protein, and a spike (S) protein (Figure 2) [77]. The coronavirus particles are pleomorphic, without a defined structure, and the RNA is contained in the N protein [78,79]. The $\mathrm{M}$ glycoprotein, known as matrix protein, forms the outside layer of the virus, forming a connection between the membrane and the $\mathrm{N}$ protein through the transmembrane domain $[78,79]$. Rather than producing the lipid envelop by itself, the virus uses the host's lipids for replication and morphogenesis $[78,79]$. The $S$ protein, prominent on the viral envelop similar to a crown, is critical for the viral entry process $[78,79]$.

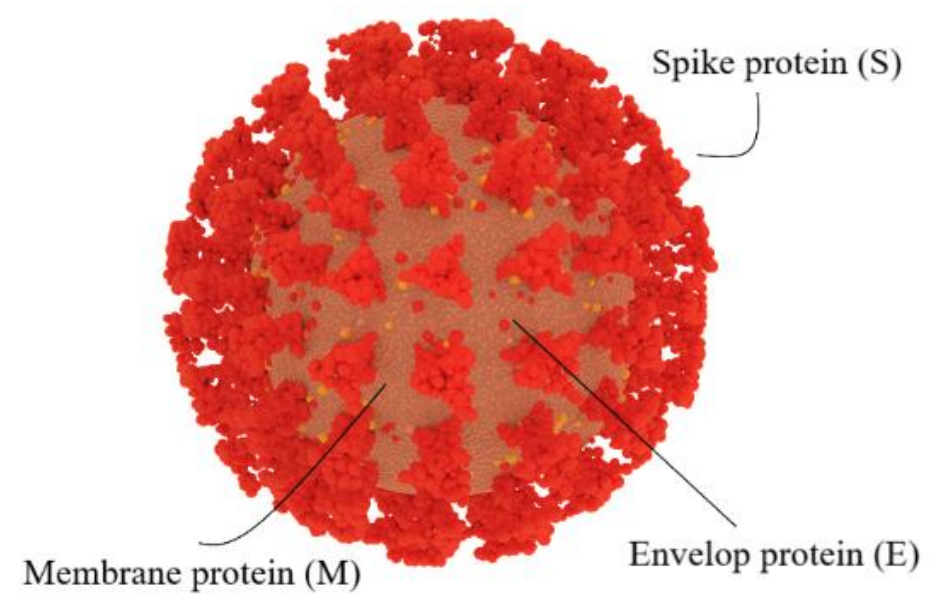

Figure 2. SARS-CoV-2 structure. Similar to other coronaviruses, SARS-CoV-2 contains a membrane (M) glycoprotein, an envelop (E) protein, a spike (S) protein, and a nucleocapsid (N) protein (not shown at the outer layer).

Although most human coronavirus infections are mild, three coronavirus-induced outbreaks-SARS, MERS, and COVID-19-burst out in the last 20 years. Notably, the two viruses causing SARS and COVID-19, namely SARS-CoV and SARS-CoV-2, share the same route in infecting humans by binding to human virus entry receptor angiotensinconverting enzyme 2 (ACE2) (Figure 3) [80-83]. Research showed that the binding affinity of SARS-CoV-2 to ACE2 was similar to or even higher than the binding affinity of SARS$\mathrm{CoV}$ to ACE2, consistent with the high structural similarity between SARS-CoV-2 and SARS-CoV [83-86]. Additionally, neuropilin-1 (NRP-1) and the tyrosine-protein kinase receptor UFO (AXL) were identified as receptors to facilitate SARS-CoV-2 infection of the human respiratory system [87-90]. The overall structural homology and high affinity to the same receptor of these two viruses may explain the high transmission rates of SARS and COVID-19 from human to human [84,85].

Similar to other coronaviruses, the SARS-CoV-2 entrance process consists of three steps (Figure 3) [91]:

1. Host cell attachment and receptor binding;

2. Host cell membrane and viral membrane fusion;

3. Viral genomic material residing in the host cell.

Coronaviruses employ a class 1 viral fusion protein, the homotrimeric $S$ glycoprotein, which protrude from the viral surface to attach and bind to cell receptors [86,92-95]. SARSCoV-2 S protein, in which a receptor-binding domain (RBD) structure is similar to that of SARS-CoV as it shares around $75 \%$ overall amino acid sequence identity, attracts ACE2 
as a receptor to infect target cells [83,96-98]. ACE2 is not only highly expressed in lower respiratory tract cells such as type II alveolar cells (AT2) of the lung, but is found in organs such as the heart, kidney, and gastrointestinal tract, as well. This presumably contributes to COVID-19-induced ARDS, heart attack, kidney failure, and digestive syndromes [91,99]. During the infusion step, the S glycoprotein-ACE2 complex is proteolytically cleaved at a polybasic cleavage motif (PPAR) at the junction of two subunits of the spike protein (S1 and S2) by type 2 transmembrane serine protease (TMPRSS2) expressed on the surface of the host cell, leading to S protein activation and conformational alterations [100-103]. Similar to other coronaviruses, the $S$ protein in SARS-CoV-2 is composed of two functional subunits, designated S1 and S2, of which the S1 subunit comprises the RBDs and stabilizes the prefusion state of the viral membrane-anchored S2 subunit $[83,95,104]$. Upon the dissociation of S1 from ACE2 by TMPRSS2, S2 undergoes a transition from a metastable pre-fusion state to a more stable post-fusion state, promoting the virus to enter target cells and release its genomic material into their cytoplasm [83,86,91-94]. Consistent with the sequencing map, S2 fusion machinery is more conserved than the S1 subunit, in line with the discovery that S1 is more exposed at the viral surface and is subject to more stringent pressure from the host immune system compared with the S2 subunit $[83,104]$. The sequence overall identity and structure conservation of non-RBD regions in the $S$ protein such as the S2 subunit suggest potential targets for neutralizing antibodies and vaccines $[83,86]$.

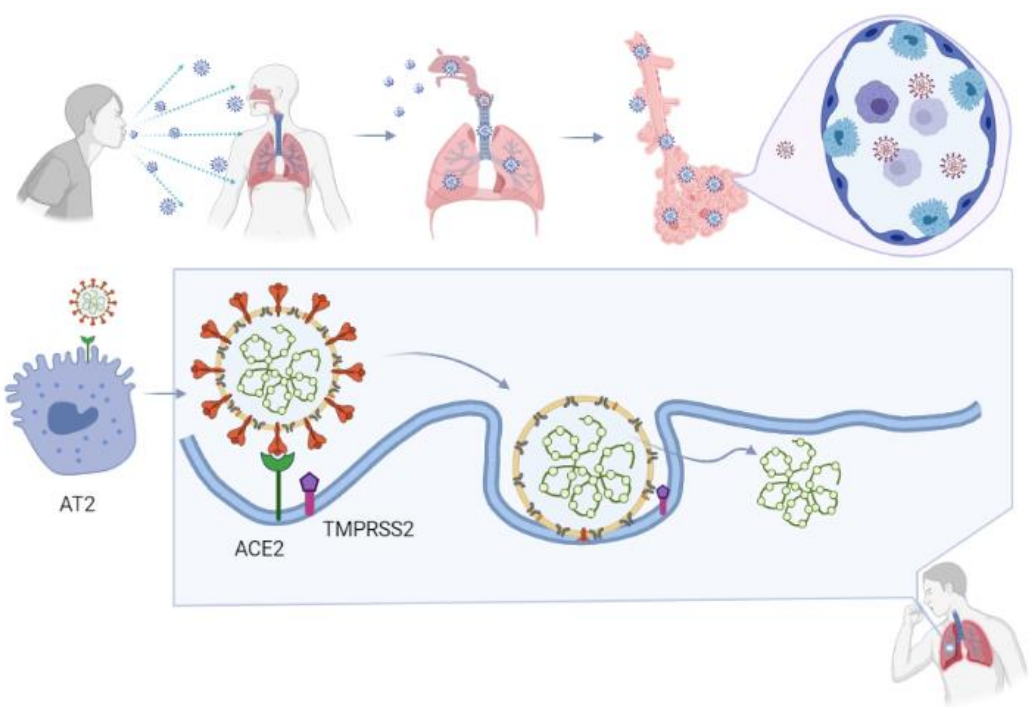

Figure 3. SARS-CoV-2 infection route. Infected COVID-19 patients can spread the virus by sneezing or coughing, or by any other route that drops the infectious particles onto another surface. When a person contracts the virus, the virus recognizes its binding target, ACE2, which is expressed on type II alveolar cells (AT2) in the lower respiratory tract. In the fusion step, the S protein on SARS$\mathrm{CoV}-2$ binds to ACE2, followed by cleavage of the $S$ glycoprotein-ACE2 complex at polybasic motif (PPAR) at S1/S2 by type 2 transmembrane serine protease (TMPRSS2) and other proteases, leading to conformational alteration and activation of the S-glycoprotein. After fusion with the host cell membrane, the virus releases its genomic material into the cytoplasm.

\section{Mutations of SARS-CoV-2}

Similar to other RNA viruses, SARS-CoV-2 may develop mutations in a relatively easier manner compared with DNA viruses, especially in the spike region due to genetic drift [85]. Genomic sequencing allows the identification and monitoring of changes in SARS-CoV-2, which helps in understanding and predicting the associated characteristics and their influence on public health [105]. The surveillance of emerging variants plays an important role in detecting viruses that spread rapidly, cause more severe symptoms, 
evade detection by diagnostic tests, reduce susceptibility to therapeutics with monoclonal antibodies, and escape natural or vaccine-induced immunity [105].

As early as March 2020, a D614G mutation was identified in the S glycoprotein of SARS-CoV-2, namely a single amino acid replacement of aspartic acid (D) with glycine (G) $[106,107]$. By April 2020, G614 has become the global dominant variant in the pandemic compared to the D614 form originally identified in the first human cases in Wuhan, China $[106,108]$. This variant is caused by an A (adenine) -to- G (guanine) nucleotide mutation at position 23,403 relative to the Wuhan reference strain, and is accompanied by three C (cytosine) -to-T (thymine) mutations: One in the 5'UTR (untranslated region) at position 241, one silent mutation at position 3307, and one missense mutation in RNAdependent RNA polymerase (RdRp P323L) at position 14,408 [106,109]. G614 is associated with potentially higher viral load in COVID-19 patients and patients of younger age, but not with disease severity or mortality, compared with its counterpart D614 form $[106,107]$.

As reported in November 2020, a unique variant of SARS-CoV-2 associated with farmed minks was identified in humans in Denmark [110]. This "Cluster 5" variant contains three substitutions (I692V and M1229I, and Y453F in RBD) and one deletion (HV 69-70 deletion, namely histidine and valine at positions 69 and 70, respectively) in the $S$ protein that had not been observed previously [111]. Concerning the multiple mutations in this variant, there was worry that viruses can potentially reduce antibody neutralization in humans, leading to attenuated immune protection [111]. With extensive investigation and surveillance, no more cases related to the Cluster 5 variant have been observed since September 2020, suggesting that it is no longer circulating [110,111]. However, variants with Y453F (tyrosine substituted by phenylalanine at position 453) mutation on the $S$ protein are still common in the Netherlands and have been reported sporadically in several other countries including the Russian Federation, South Africa, Switzerland, and the USA [111].

More complicated than the above variants, lineage B.1.1.7 (also known as 20B/501Y.V1) is a phylogenetic cluster that is widespread and outcompeting an existing population of circulating variants with a more transmissibility rate observed in the United Kingdom [108]. B.1.1.7 contains an unusually large number of mutations, particularly in the $\mathrm{S}$ protein, in which N501Y (asparagine replaced by tyrosine at position 501, one of the key contact residues in RBD) was correlated with potentially higher binding affinity to human and mouse ACE2 [112-114]. Globally, two other variants with multiple S protein mutations including N501Y but without HV 69-70 deletions have been circulating rapidly in Australia and South Africa [115,116]. In addition to N501Y, lineage B.1.1.7 was identified with other mutations, including thirteen non-synonymous mutations, three deletions, and six synonymous mutations which may be induced by chronic infection [112]. Since December 2020, N501Y has become the top variant of SARS-CoV-2 worldwide, identified in more than 1.1 million individual samples sequenced for COVID-19 virus and clinically recorded since its first detection in February $2020[117,118]$. Since June 2021, the T478K and L452R variants are growing quickly, culminating to 1 million in a total of the sequenced samples. These variants are among the top ten harboring RBD region mutations (the variants also include T478K, K417T, S494P, F490S, S477N, N439K, L452R, K417N, and E484K) [117,118].

\section{The immunological Changes Associated with COVID-19}

When the viral infection starts (i.e., when SARS-CoV-2 reaches the cells that line the respiratory tract), the host responds by triggering the immune system to fight back. Although most patients recover successfully, a few but a non-negligible proportion of infected patients develop severe symptoms characterized by severe pneumonia, ARDS, lymphopenia, exhausted lymphocytes, cytokine storm, and possibly antibody-mediated enhancement of viral entry $[47,119,120]$. While the immune response attempts to defend against the infection, variable(s) yet to be clearly elucidated often counterbalance immune benefits leading patients to be hospitalized. Although the symptoms and outcomes are 
extraordinarily heterogeneous, understanding the relationship between disease severity and the various immunological changes that occur is under intense investigation [121].

In general, when humans are virally infected, specific cells produce interferons to block viruses from reproducing. Furthermore, the immune system marshals antibodies to target the invaders [122]. Specifically, IFN- $\gamma$ (interferon-gamma)—a lymphokine secreted by activated T cells-directs and regulates the synthesis of IP-10 (IFN- $\gamma$-inducible protein10), a protein involved in the inflammatory response [123]. IP-10 directs the recruitment of T-helper-1 (Th1) cells for both normal host defense against intracellular pathogens of the lung and acute and chronic inflammatory processes [124]. For example, studies in mice showed that a strong interferon response is crucial in the timely resolution of SARS$\mathrm{CoV}$ and MERS-CoV infections. Alternatively, lethal inflammatory immune reactions are activated if the interferon response is delayed [125,126]. Significantly increased IP-10 levels have been shown in both SARS and MERS patients by independent groups over the past years $[127,128]$.

In addition to the COVID-19 common symptoms such as fever and dry cough, bilateral patchy shadows, or ground-glass opacity on chest CT images, indicate lung damage. Together with CT scans that reveal damage to the lung, patients also present with high levels of IL-1B (interleukin-1B, an inflammatory cytokine), IFN- $\gamma$ (T helper cytokine), IP-10, and MCP-1 (monocyte chemoattractant protein-1), which is similar to the association of these pro-inflammatory cytokines with pulmonary inflammation in SARS patients $[47,129]$. Depressed total lymphocytes counts (lymphopenia), prolonged prothrombin duration, and elevated lactate dehydrogenase were documented as the three most common abnormalities in hospitalized patients [46]. One of the early clinical reports in the city of Wuhan observed that compared to non-ICU patients, ICU patients had higher plasma levels of IL-2 (interleukin-2, a T helper cytokine), IL-7 (interleukin-7, a cytokine essential for lymphoid cell survival), IL-10 (interleukin-10, an anti-inflammatory cytokine), GCSF (granulocyte colony-stimulating factor), IP-10, MCP-1, MIP1 $\alpha$ (macrophage inflammatory protein $1 \alpha$, a small inducible cytokine involved in inflammatory responses), and TNF- $\alpha$ (tumor necrosis factor $\alpha$, a pro-inflammatory cytokine) $[47,130,131]$. It was also found that white blood cell count, neutrophil count, the levels of D-dimer (indicator for blood vessel dysfunction and clot formation), blood urea, and creatinine levels continued to increase, while lymphocyte counts continued to decrease in non-surviving patients [46,132]. Despite COVID-19 being such a heterogeneous disease affecting patients with different ethnicities, ages, and underlying conditions, the triad of cytokines IP-10, IL-10, and IL-6 was identified to be severity-related, which might help in anticipating disease progression and the length of hospitalization [133].

\section{Therapeutic Strategies}

In general, three pathologic mechanisms might be associated with poor prognosis [46]:

Virus-induced neutrophilia related to the cytokine storm;

The sustained inflammatory process related to activated coagulation;

Virus-caused hypoxia and shock related to multi-organ dysfunction.

Hence, a cytokine storm, which is associated with high concentrations of pro-inflammatory cytokines in the plasma, is positively correlated with the severity of COVID-19 [47].

Several approaches to treat COVID-19 have been advocated. Symptomatic management and oxygen therapy are two mainstay clinical treatments [119]. Furthermore, in early studies, convalescent plasma transfusion showed an effective clinical outcome for patients with severe and critical symptoms. Whereas the preliminary data were promising, a retrospective study calculated that the effective rate was below $60 \%[134,135]$. In a survey of 16,287 UK hospitalized patients, the convalescent plasma treatment made no significant improvement in the survival of patients who received the treatment compared to those who did not [136]. Numerous clinical trials have been undertaken to explore additional options to treat COVID-19, with 7662 COVID-19 ongoing studies, among which 1382 studies focus on pharmaceuticals $[137,138]$, as highlighted below. 
In a retrospective study of clinical treatment of hospitalized COVID-19 patients in early 2020, most patients received antiviral therapy (oseltamivir), many received antibacterial therapy (moxifloxacin, ceftriaxone, or azithromycin), and a few received glucocorticoid therapy when no specific treatment was recommended except supportive care in early 2020 [46]. Antibacterial drugs proved to be ineffective, and neither oseltamivir nor methylprednisolone (a strong corticosteroid) improved outcomes. Among those admitted into the ICU-patients who also often presented with hypertension, diabetes, cardiovascular disease, or cerebrovascular disease-high-flow oxygen therapy, non-invasive ventilation, and invasive ventilation (including extracorporeal membrane oxygenation as a rescue therapy) were applied according to specific individual situations [46].

During the early chaotic period of the COVID-19 pandemic, no antiviral drugs were efficacious until remdesivir showed limited improvement in shortening the recovery time in hospitalized adult patients [139]. Nonetheless, the cytokine storm-induced morbidity and mortality remained elevated [140]. Baricitinib, an inhibitor targeting the intracellular signaling pathway of cytokines, including IL-6, IL-10, IFN- $\gamma$, and GMCSF (granulocytemacrophage colony-stimulating factor), improved patients' quality of life. It also reduced conventional inflammatory parameters and IFN biomarkers (serum IP-10 level and 25gene IFN score) in clinical trials treating monogenic IFN-mediated auto-inflammatory diseases [141]. Recently, the United States Food and Drug Administration (FDA), issued an emergency use of the anti-inflammatory drug baricitinib, in combination with the antiviral drug remdesivir, for the treatment of dysregulated inflammation for severe COVID-19 patients [142]. It was found that baricitinib plus remdesivir were superior to remdesivir alone in shortening the recovery time and improving clinical status with fewer serious adverse events in patients with COVID-19 [143].

Although the US FDA has authorized the emergency use of baricitinib in combination with remdesivir, additional investigation of treatment methods is needed due to the many confounding factors. The compensating effect of other key events in the involved molecular pathways is always a complicated issue for molecular targeting drugs. This is also the reason for clinical trials with various drug combinations, conducted in the hope of obtaining co-effective outcomes such as shortened recovery and reduced mortality. Considering the unbalanced immune conditions in severely ill patients, the mortality rate was not reduced significantly, although there was some improvement (Figure 4).

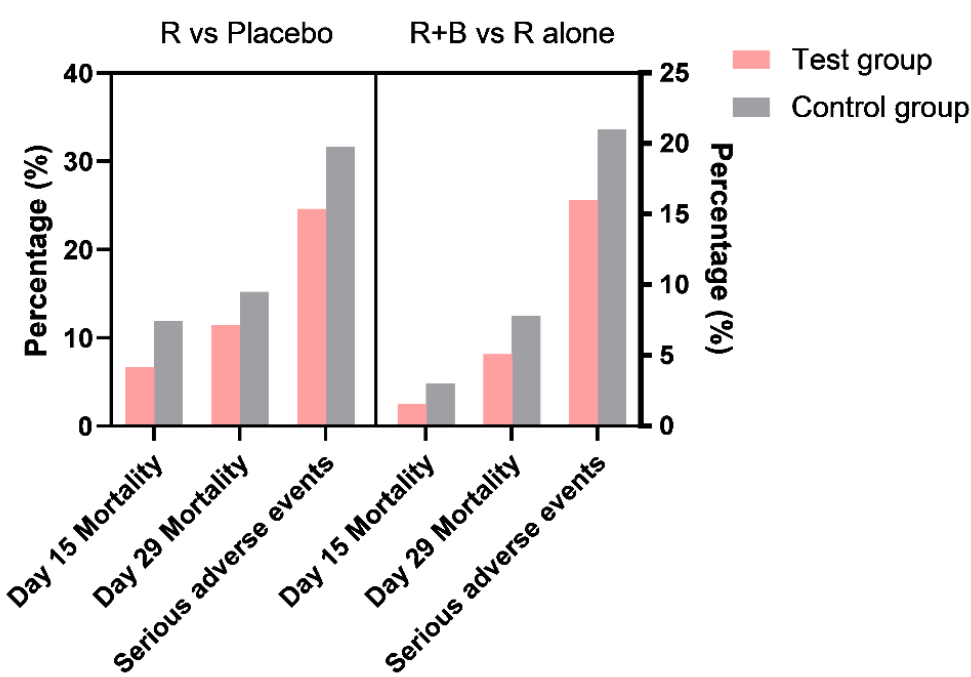

Figure 4. Remdesivir versus remdesivir plus baricitinib clinical trials. Comparison of mortality rate and serious adverse events of two clinical trials regarding remdesivir $(R)$ compared with a placebo, and remdesivir in combination with baricitinib $(R+B)$ compared with remdesivir alone $(R$ alone). Data source: Remdesivir for the Treatment of COVID-19-Final Report [139], Baricitinib plus Remdesivir for Hospitalized Adults with COVID-19 [143]. 


\section{Vaccine Development}

As an important pandemic control measure, various groups began seeking a safe and effective vaccine for this highly transmissible disease once the SARS-CoV-2 genome sequence was released [144,145].

The classical vaccine platforms commonly used for humans include a whole-inactivated virus, live-attenuated virus, protein subunit, and virus-like particle [146]. These platforms successfully prevented polio, MMR (measles, mumps, and rubella), seasonal influenza, and human papillomavirus, respectively [146]. As of August 2021, four out of 20 vaccines under the WHO evaluation process have been based on classical platforms, such as inactivated antigens [147]. Traditional virus-based vaccine development methods, such as attenuated or inactivated pathogens, although effective, require a large number of active viruses that only biosafety level 3 laboratories can safely produce in the case of COVID-19 [148]. Rather than dependence on the ability to culture live viruses, sequence information of the viruses alone can initiate the development of next-generation vaccines, leading to highly adaptable platforms in facing pandemics such as COVID-19 [146]. The next-generation platforms include viral vector vaccines, nucleic acid-based vaccines (DNA or mRNA), and antigenpresenting cells. For these platforms, the vesicular stomatitis virus-based Ebola virus vaccine (rVSV-ZEBOV) is a representative example-a recombinant, replication-competent vaccine consisting of a VSV vector engineered to express the main glycoprotein of the Zaire Ebola virus [146,149,150]. According to the WHO, as of 13 August 2021, 110 COVID-19 vaccine candidates are in clinical development, among which the protein subunit platforms account for $34 \%$, followed by non-replicating viral vector, DNA, inactivated virus, and RNA platforms $(15 \%, 9 \%, 15 \%$, and $16 \%$, respectively) [151]. Interestingly, intramuscularly injectable candidate vaccines with two doses were found to be the preferred choice among the candidates in the pre-clinical phase, compared with vaccines with other dosages (one dose or three doses) and routes of administration (oral, subcutaneous, intradermal, or intranasal) [151].

Having been studied for more than three decades, the use of mRNA is not a novel approach for vaccine development $[152,153]$. The search for effective vaccine tools that can be quickly designed and applied with flexible adaptiveness to antigenic changes in circulating strains is constant, together with updated strategies to combat newly emerging viruses and potential pandemics [146]. Previous efforts to combat SARS and MERS outbreaks accelerated the understanding of the epidemiology, pathogenesis, and diagnosis of SARS-CoV-2, contributing to the accelerated development of therapies as well as vaccines $[148,154]$. Although the pandemic worsened for almost 1 year until the first COVID-19 vaccine was developed, the turnaround cycle of a mature product for such broad recipients has been lightning-fast compared with vaccines for measles ( 10 years), hepatitis B ( 15 years), and especially meningitis ( $\sim 90$ years) [145].

Late in 2020, two mRNA-based vaccines were sequentially granted emergency use authorization by the FDA: The Pfizer-BioNTech (on 11 December 2020) and Moderna (on 18 December 2020) COVID-19 vaccines $[155,156]$. Pfizer-BioNTech (a more than 170-yearold pharmaceutical conglomerate collaborating with a previously little-known German biotechnology company) developed a lipid nanoparticle-formulated, nucleoside-modified mRNA (modRNA) vaccine called BNT162b2, which encodes the membrane-anchored pre-fusion full length of SARS-CoV-2 S protein whose conformation is locked by two proline mutations [157]. Most vaccinated healthy adults in phase 1 and 2 clinical trials produced S-specific CD8+ and type 1 helper T-cells (Th1 CD4+) with a high serum level of IFN- $\gamma$ [157]. Although another candidate called BNT162b1, which encodes a secreted trimerized SARS-CoV-2 receptor-binding domain, showed a similar immunogenicity profile (antibody responses), BNT162b2 elicited a milder systemic reactogenicity profile (such as fatigue, headache, and fever) than what BNT162b1 caused in recipients, particularly in the elderly [158]. This stimulated further phase 2 and 3 clinical trials with the BNT162b2 vaccine, with the two-dose regimen showing high efficacy irrespective of age, sex, ethnicity, body-mass index, and pre-existing comorbidities [159,160]. 
Similar to Pfizer, Moderna (a pioneer mRNA biotech company founded in 2010), in collaboration with the Vaccine Research Center of the US National Institute of Allergy and Infectious Diseases (NIAID), developed a lipid nanoparticle-encapsulated mRNA vaccine called mRNA-1273, which encodes a pre-fusion stabilized full-length SARS-CoV-2 S protein [161,162]. In preclinical studies in nonhuman primate models, mRNA-1273 induced Th1 CD4+ cells and interleukin-21-producing CD4 T follicular helper (Tfh) cell responses, with low or undetectable Th2 or CD8 T-cell responses [163]. In addition to detecting robust SARS-CoV-2 neutralizing activity, rapid protection of airways, and absence of pathologic alterations in the lung of nonhuman primates, a phase 3 clinical trial involving more than 30,000 volunteers proved the mRNA-1273 vaccine to be effective in preventing COVID-19 without safety concerns $[163,164]$.

Almost simultaneously to Pfizer and Moderna, Oxford University and AstraZeneca developed a recombinant adenovirus vaccine for COVID-19 consisting of a replicationdeficient chimpanzee adenoviral vector (ChAdOx1), which contains the gene that encodes the codon-optimized full length of SARS-CoV-2 S protein $[165,166]$. This vaccine was redesigned from ChAdOx1 MERS, and a single dose of the vaccine proved to be protective for nonhuman primates (rhesus macaques) against MERS-CoV-induced disease [166,167]. In preclinical studies, ChAdOx1 nCoV-19 vaccine elicited robust humoral and cellular immune responses in both mice (strong Th1 response with high levels of IFN- $\gamma$ and TNF- $\alpha$ and low levels of IL-4 and IL-10) and rhesus macaques (significantly increased spikespecific antibodies after the second immunization and detectable $\mathrm{T}$ cell responses when challenged by S protein) [166]. Follow-up clinical trials showed that, compared to the $~ 95 \%$ efficacy of Pfizer-BioNTech (BNT162b2) and Moderna (mRNA-1273) vaccines, the overall efficacy of the Oxford-AstraZeneca COVID-19 vaccine (ChAdOx1 nCoV-19) was above $70 \%: 60 \%$ in the group receiving two standard doses (SD/SD cohort, $5 \times 10^{10}$ viral particles per dose), and $90 \%$ in the group receiving a half-dose followed by a standard dose (LD/SD cohort), respectively [165]. Unlike the two previously mentioned vaccines, ChAdOx1 $\mathrm{nCoV}-19$ is the first reported non-profit vaccine, committed to low-income and middleincome countries with a promised price of USD 2-3 per dose [168-170]. In particular, concerning transportation, the ChAdOx1 $\mathrm{nCoV}-19$ vaccine can use routine refrigerated cold-chain delivery $\left(2-8{ }^{\circ} \mathrm{C}\right)$, which is more affordable and practical compared with the ultra-low temperature freezers $\left(-80^{\circ} \mathrm{C}\right)$ required for mRNA-based vaccines $[165,168]$. On 15 February 2021, the WHO listed two additional versions of ChAdOx1 nCoV-19produced in the Republic of Korea and in India, rolling them out for emergency use in more than 70 countries across six continents and heading to cover 142 countries [171,172]. Several European Union (EU) countries temporarily suspended the use of this vaccine due to reports of 37 thrombotic events, including 15 deep vein thrombosis cases and 22 pulmonary embolism cases, among over 17 million vaccinated individuals in the EU and UK $[172,173]$. The decision was taken even though the number of thrombotic events in vaccinated individuals is significantly lower than what naturally occurs in a similar size cohort. Considering that the vaccine was not designed to address medical issues other than preventing COVID-19, the WHO, along with other EU countries, have advised continuation of the use of ChAdOx1 nCoV-19-based vaccine [172].

Although viruses may sustain genetic drift, there is the confidence that the homogeneous protein produced by the spike gene construct would maintain most neutralizationsensitive epitopes [85]. Undoubtedly, functional studies on viral proteins can play an important role in antiviral drug screening and vaccine development with the assistance of next-generation platforms, which may permanently change our ability to respond to newly emerging viruses $[96,146]$. As for how long antibody protection induced by natural infection lasts, this is still unknown. Vaccination against SARS-CoV-2 regardless of antibody status is currently recommended. Follow-up time will inform how long the vaccine-induced antibody protection can last [174]. For detailed information on COVID19 vaccines in clinical development, refer to Table S1 which is adjusted from the WHO document [151]. Although a few claim vaccination is ineffective for limiting contagion, 
especially considering the vaccine breakthrough by the Delta variant (B.1.617.2) [175-179], vaccination is still recommended for everyone ( $\geq 12$ years old) to prevent COVID-19 and particularly to avoid hospitalization and death [180].

\section{The History of Low-Dose Radiotherapy of Non-COVID-19 Pneumonia}

Radiation therapy, which has been used to treat cancer for more than 100 years, is not new in disease management. After the discovery of X-rays in 1895 and the development of therapeutic methods in the early1900s, clinicians have used radiation to kill malignant cells [181]. Unlike the relatively high doses used to sterilize tumors, lower doses were also applied in treating non-cancerous diseases.

Low-dose radiotherapy, in which the total dose applied is significantly less than the dose used in cancer treatments, was historically a successful option for pneumonia before the discovery of penicillin [182,183]. Reports have suggested that an absorbed dose of $1 \mathrm{~Gy}$, which is 50 to 100 times lower than the total doses used by oncologists, has antiinflammatory effects $[183,184]$. As early as 1905, Musser and Edsall reported on their X-ray treatment of five patients with unresolved pneumonia, which shed the first light on the potential benefit of radiation in treating respiratory diseases [185]. Almost two decades later, Heidenhain and Fried observed a systematic inflammatory-blocking function of low-dose X-ray treatment, showing clinical utility in treating deeper penetrating infections such as pneumonia [186].

In most follow-up studies performed in the 1930s, the applied doses ranged from 0.3 to 0.5 Gy [187]. In 1936, Powell applied low-dose radiotherapy in a clinical study with 231 patients after his first success on a patient with a complete recovery from lobar pneumonia [188]. A concern is that Powell did not randomize his patients as his staff recognized near-immediate relief from respiratory distress and circulatory distress after treatment $[183,187,188]$. In a study that appeared soon after, Scott noted that the patients experienced initial relief of symptoms, followed by a reduction of fever [189]. Surprisingly, no record of any toxicity events in the treatment group was noted as the investigators monitored for adverse radiation effects [189]. However, it may be argued that longer followup periods may have revealed a different spectrum of health effects. In 1942, Rousseau reported a full clinical recovery in the majority of patients with atypical sulfanilamide non-responsive pneumonia treated with low-dose radiotherapy, noting that the patients were free from toxic side effects [190]. In the following year, Oppenheimer reported that presumed-viral pneumonia patients treated with X-rays also showed complete fever resolution and disappearance of pulmonary consolidations [191]. Details of the brief history of X-ray therapy on non-COVID-19 patients are listed in Table 1.

In short, the early reports suggest that low-dose radiotherapy can reduce mortality rate, alleviate symptoms rapidly, and substantially reduce the severity of pneumonia [183]. Although the reported toxic effects of low-dose radiotherapy were minimal, systematic, evidence-based reasoning for the mechanisms underlying the efficacy of low-dose radiotherapy is needed. The promising early studies did not last long with the discovery of penicillin shifting scientific focus and funding mechanisms on antibiotics. Furthermore, there were safety concerns about long-term adverse outcomes including cancer and other degenerative diseases. The silence on the efficacy of low-dose radiotherapy was broken after 80 years as the global pandemic brought scientists to consider again the anti-inflammatory effects of low-dose radiotherapy in attenuating the severity of life threatening symptoms of COVID-19 [192]. 
Table 1. Brief History of X-ray Therapy on non-COVID-19 Pneumonia.

\begin{tabular}{|c|c|c|c|c|c|c|c|c|c|}
\hline Time & Author & Location & Radiation Type & Dosage & $\begin{array}{l}\text { Patients } \\
\text { Number }\end{array}$ & Diseases/Conditions & Result & $\begin{array}{c}\text { Adverse } \\
\text { Radiation } \\
\text { Effects }\end{array}$ & Reference \\
\hline 1905 & $\begin{array}{l}\text { Musser and } \\
\text { Edsall }\end{array}$ & Pennsylvania & X-ray & $\mathrm{N} / \mathrm{A}$ & 5 & $\begin{array}{l}\text { Unresolved } \\
\text { pneumonia }\end{array}$ & $\begin{array}{l}40 \% \text { symptoms } \\
\text { disappeared }\end{array}$ & $\mathrm{N} / \mathrm{A}$ & [185] \\
\hline 1907 & $\begin{array}{l}\text { Edsall and } \\
\text { Pemberton }\end{array}$ & Pennsylvania & X-ray & Various & 2 & $\begin{array}{l}\text { Unresolved } \\
\text { pneumonia }\end{array}$ & $100 \%$ cured & $\mathrm{N} / \mathrm{A}$ & [193] \\
\hline 1916 & $\begin{array}{c}\text { Quimby and } \\
\text { Quimby }\end{array}$ & New York & X-ray & Not given & 12 & $\begin{array}{l}\text { Chronic chest } \\
\text { conditions }\end{array}$ & $\begin{array}{l}100 \% \text { prompt } \\
\text { benefit }\end{array}$ & $\mathrm{N} / \mathrm{A}$ & [194] \\
\hline 1924 & $\begin{array}{l}\text { Heidenhain and } \\
\text { Fried }\end{array}$ & $\begin{array}{l}\text { Worms, } \\
\text { Germany }\end{array}$ & X-ray & Low doses & 243 & $\begin{array}{l}\text { Unresolved chronic } \\
\text { bronchopneumonia }\end{array}$ & $\begin{array}{l}75 \% \text { good and } \\
\text { very good } \\
\text { improvement }\end{array}$ & $\mathrm{N} / \mathrm{A}$ & [186] \\
\hline 1925 & $\begin{array}{c}\text { Krost } \\
\text { (cooperation } \\
\text { with M.T. } \\
\text { Blumenthal) }\end{array}$ & Chicago & X-ray & Small doses $(*)$ & 12 & $\begin{array}{c}\text { Unresolved } \\
\text { pneumonia (children) }\end{array}$ & $\begin{array}{l}92 \% \text { apparent } \\
\text { benefit }\end{array}$ & None & [195] \\
\hline 1930 & $\begin{array}{l}\text { Merritt and } \\
\text { McPeak }\end{array}$ & $\mathrm{N} / \mathrm{A}$ & X-ray & $\mathrm{N} / \mathrm{A}$ & 7 & $\begin{array}{l}\text { Unresolved } \\
\text { pneumonia }\end{array}$ & $86 \%$ cured & $\mathrm{N} / \mathrm{A}$ & [196] \\
\hline 1936 & Powell & Houston, Texas & X-ray & $\mathrm{N} / \mathrm{A}$ & 47 & $\begin{array}{c}\text { Unresolved } \\
\text { pneumonia (lobar?) }\end{array}$ & $\begin{array}{c}100 \% \\
\text { convalescence } \\
\text { with } 2.5 \% \\
\text { mortality }\end{array}$ & $\mathrm{N} / \mathrm{A}$ & [188] \\
\hline 1938 & Powell & Temple, Texas & X-ray & Small doses (!) & 104 & Lobar pneumonia & $\begin{array}{l}\text { Mortality rate } \\
\text { less than } 5 \%\end{array}$ & $\mathrm{~N} / \mathrm{A}$ & [197] \\
\hline 1938 & Powell & Temple, Texas & X-ray & small doses (!) & 30 & Bronchopneumonia & $\begin{array}{l}\text { Mortality } \\
\text { reduced from } \\
30 \% \text { to } 13 \%\end{array}$ & $\mathrm{~N} / \mathrm{A}$ & [197] \\
\hline 1939 & Powell & $\mathrm{N} / \mathrm{A}$ & X-ray & $\mathrm{N} / \mathrm{A}$ & $\mathrm{N} / \mathrm{A}$ & Acute pneumonias & $\mathrm{N} / \mathrm{A}$ & $\mathrm{N} / \mathrm{A}$ & [198] \\
\hline 1939 & Scott & Niagara Falls & X-ray & $\mathrm{N} / \mathrm{A}$ & 138 & $\begin{array}{l}\text { Acute Lobar } \\
\text { pneumonia }\end{array}$ & $80 \%$ cured & None & [189] \\
\hline
\end{tabular}


Table 1. Cont.

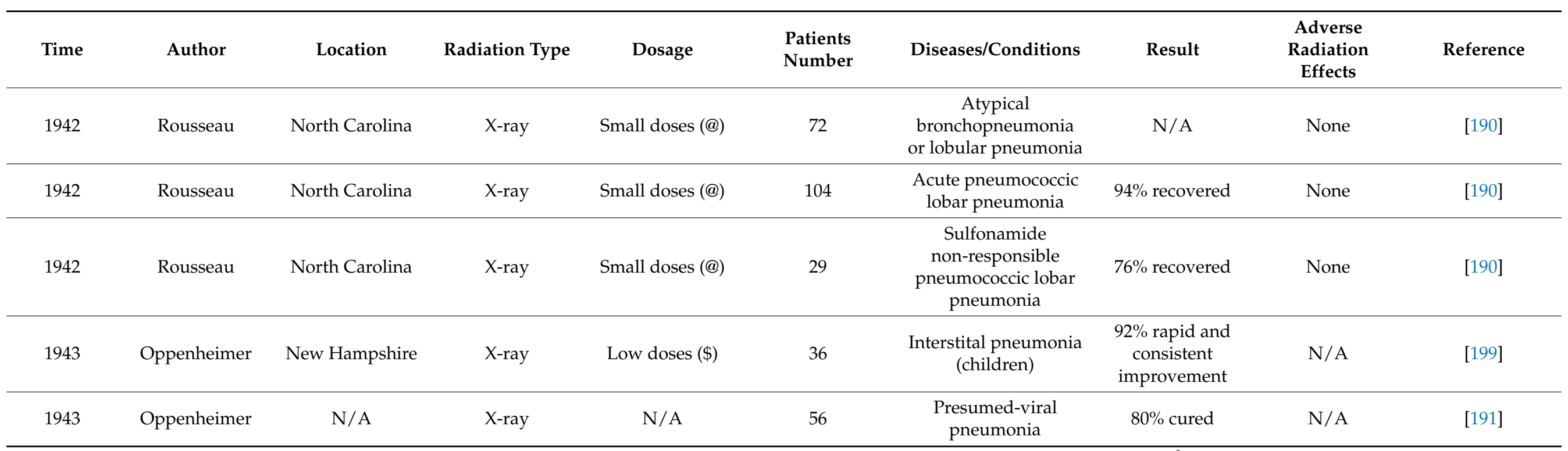

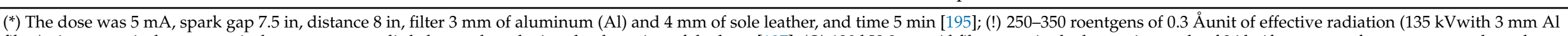

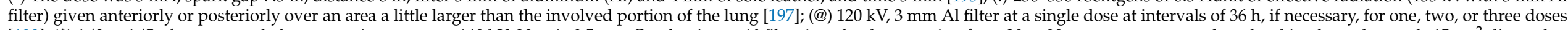

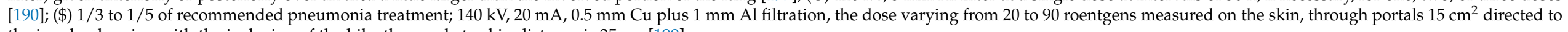
the involved region with the inclusion of the hila; the anode to skin distance is $35 \mathrm{~cm}$ [199]. 


\section{Low-Dose Radiation Treatment of COVID-19}

Although COVID-19 pneumonia is a novel disease that is different from other types of ARDS, severe COVID-19-associated ARDS shares typical ARDS lung pathology such as diffuse alveolar damage and hyaline membrane formation [120,200]. As Prasanna et al. summarized, the general rational for low-dose radiation treatment of COVID-19 is its inhibition of the cytokine storm, which promotes pulmonary dysfunction and ultimately ARDS [201]. Inflammation is a dynamic and progressive process that is tightly associated with redox-modulated reactions [202]. When recruited to sites of inflammation, macrophages and neutrophils generate reactive species, including reactive oxygen and nitrogen species (ROS and RNS). With multiple pro-inflammatory cytokines and chemokines being secreted, the latter together with elevated levels of ROS and RNS deteriorate redox homeostasis, and further worsen the disease [203]. During the past two decades, research has revealed that low-dose radiation-mediated homeostasis is associated with enhanced cellular detoxification of ROS by a major antioxidant enzyme (manganese superoxide dismutase, MnSOD) within the mitochondria [204-207]. This adaptive protection of mitochondrial metabolic functions is thought to provide experimental and theoretical support for using low-dose radiation to limit virus replication [207]. Other antioxidants, including glutathione, were also shown to be increased following exposure to low doses of sparsely ionizing radiation such as $X$ and $\gamma$ rays [208,209]. Schaue et al. suggested that it might be difficult and challenging for patients with complicated conditions and advanced age to rebalance redox levels, and low-dose radiation treatment might be of clinical value with its broad suppression of various inflammatory, pro-oxidant pathways at multiple levels $[203,210]$.

Among the over 6000 clinical trials on COVID-19, only 17 focus on the relative efficacy of low-dose radiation therapy [211]. In June 2020, clinicians at Emory University reported their phase I interim analysis of a small pilot trial to treat oxygen-dependent elderly patients with COVID-19 pneumonia. They found that four out of five patients rapidly improved their breathing within $24 \mathrm{~h}$ after a single fraction of $1.5 \mathrm{~Gy}$ of X-rays applied to both lungs [212]. The patients recovered to breathe room air (unmodified, ambient air with a typical oxygen concentration of $21 \%$ ) after being on supplemental oxygen for an average of 1.5 days after whole-lung irradiation [212,213]. Thereafter, clinical trials conducted in Iran found improvements similar to those observed in the latter study. An 80\% response rate was observed in severe COVID-19 patients after whole-lung irradiation with a single fraction of $0.5 \mathrm{~Gy}$ [214]. These preliminary observations support the hypothesis that radiation at doses of $\sim 0.5$ Gy modifies the immune reaction to COVID-19 pneumonia by activating anti-inflammatory M2 macrophages [215]. Following up on the safety outcomes of the phase I trial, the same clinicians at Emory University carried out a phase II trial exploring the efficacy of immunomodulatory, single fraction, whole-lung moderate-dose of 1.5 Gy for patients with SARS-CoV-2 hyper-inflammatory pneumonia [216]. They reported a significantly shorter time of 3 days to clinical recovery in the radiotherapy cohort compared to 12 days in the control cohort. They also noticed significantly reduced levels of the inflammatory biomarker CRP (C-reactive protein) and LDH (lactate dehydrogenase), which suggest modulatory effects on immune cells. In November 2020, another pilot study in India showed a 90\% response rate for low-dose radiotherapy (0.7 Gy in a single fraction) in COVID-19 patients having moderate to severe disease, which further supports the feasibility and clinical effectiveness of low-dose radiotherapy [217]. Overall, all of these clinical trials reported no early toxic effect of low-dose radiation (LDR). However, in February 2021, a study from Switzerland reported an identical survival rate (63.6\%) in both 1 Gy-whole-lung radiation treated and sham treated groups, although the standard treatment of dexamethasone to ICU patients may have masked the anti-inflammatory effects of low-dose radiation [218]. Details of current radiation treatment of COVID-19 patients are listed in Table 2 (completed trials) and Table 3 (ongoing trials). 
Table 2. Summary of Completed Clinical Trials Using Radiation in the Treatment of COVID-19.

\begin{tabular}{|c|c|c|c|c|c|c|c|c|c|c|c|c|c|c|}
\hline $\begin{array}{l}\text { ClincalTrial.gov } \\
\text { ID }\end{array}$ & Acronym & Dosage & Fraction & Participants & Control & $\begin{array}{l}\text { Median } \\
\text { Age/Range }\end{array}$ & $\begin{array}{c}\text { Female } \\
\text { Percentage }\end{array}$ & Phase & $\begin{array}{c}\text { Overall } \\
\text { Recovery }\end{array}$ & $\begin{array}{c}\text { Mean Time } \\
\text { to Clinical } \\
\text { Recovery }\end{array}$ & $\begin{array}{c}\text { Mean Time } \\
\text { to } \\
\text { Discharge }\end{array}$ & $\begin{array}{l}\text { No Acute } \\
\text { Toxicities }\end{array}$ & Locations & Reference \\
\hline \multirow[b]{2}{*}{ NCT04366791 } & \multirow{2}{*}{$\begin{array}{l}\text { RESCUE } \\
1-19\end{array}$} & \multirow[b]{2}{*}{1.5 Gy } & \multirow[b]{2}{*}{ Single } & 10 & No & $90(64-94)$ & $80 \%$ & 1 & $80 \%$ & 1.5 days & 12 days & No & \multirow[b]{2}{*}{ USA } & [212] \\
\hline & & & & 20 & 10 & $76(43-104)$ & $55 \%$ & 2 & $90 \%$ & 3 days & 12 days & No & & [216] \\
\hline NCT04394182 & $\begin{array}{l}\text { ULTRA- } \\
\text { COVID }\end{array}$ & $0.8 \mathrm{~Gy}$ & Single & 15 & No & 80,65 & $50 \%$ & 1 & $100 \%$ & Various $\left({ }^{*}\right)$ & 11 days & No & Spain & [219] \\
\hline NCT04394793 & $\mathrm{N} / \mathrm{A}$ & 70 cGy & Single & 10 & No & $51(38-63)$ & $0 \%$ & $\mathrm{~N} / \mathrm{A}$ & $90 \%$ & 3-7 days & 15 days & No & India & [217] \\
\hline \multirow[b]{2}{*}{ NCT04390412 } & \multirow[b]{2}{*}{$\mathrm{N} / \mathrm{A}$} & $0.5 \mathrm{~Gy}$ & Depends (!) & 5 & No & $69(60-84)$ & $20 \%$ & \multirow[b]{2}{*}{1 and 2} & $75 \%$ & 1 day & 6 days & No & \multirow[b]{2}{*}{ Iran } & [214] \\
\hline & & $0.5 \mathrm{~Gy}, 1 \mathrm{~Gy}$ & Depends (\#) & 10 & No & $75(60-87)$ & $20 \%$ & & $55.5 \%$ & $\mathrm{~N} / \mathrm{A}$ & 8.7 days & No & & [220] \\
\hline NCT04598581 & $\begin{array}{c}\text { COVID-RT- } \\
01\end{array}$ & $1 \mathrm{~Gy}$ & Single & 22 & $\begin{array}{c}\text { Sham } \\
\text { irradiation }\end{array}$ & $75(54-84)$ & $23 \%$ & 2 & $73 \%(\$)$ & N/A & N/A & No & Switzerland & [218] \\
\hline NCT04534790 & N/A & $1 \mathrm{~Gy}$ & Single & 30 & $\begin{array}{l}\text { Not radio- } \\
\text { therapy }\end{array}$ & N/A & N/A & N/A & N/A & N/A & N/A & N/A & Mexico & [221] \\
\hline NCT04724538 & N/A & $\begin{array}{l}99 \text { mTc- } \\
\text { pertechnetate } \\
\text { aerosol }\end{array}$ & N/A & 25 & $\begin{array}{c}\text { No } \\
\text { intervention }\end{array}$ & N/A & N/A & 1 and 2 & N/A & N/A & N/A & N/A & Russian & [222] \\
\hline
\end{tabular}

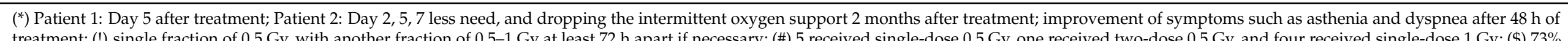

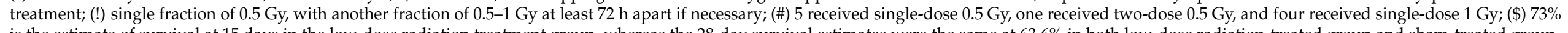

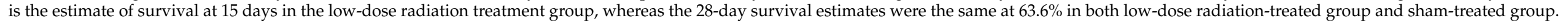

Table 3. Summary of Current Ongoing Clinical Trials Using Radiation Therapy for COVID-19.

\begin{tabular}{|c|c|c|c|c|c|c|c|c|}
\hline ClincalTrial.gov ID. & Acronym & Dosage & Fraction & Participants & Control & Phase & Locations & Reference \\
\hline NCT04433949 & RESCUE1-19 & $\leq 1 \mathrm{~Gy}$ & Single & 52 & Not radiotherapy & 3 & US & [223] \\
\hline NCT04414293 & COVRTE-19 & LDR & Single & 41 & No control group & 2 & Spain & [224] \\
\hline NCT04427566 & VENTED & $80 \mathrm{cGy}$ & Depends (\$) & 24 & No control group & 2 & US & [225] \\
\hline NCT04393948 & $\mathrm{N} / \mathrm{A}$ & $\begin{array}{l}100 \text { cGy: single lung or } \\
\text { whole lung }\end{array}$ & Single & 48 & Not radiotherapy & 1 and 2 & US & [227] \\
\hline NCT04493294 & $\mathrm{N} / \mathrm{A}$ & LDR & Single & 500 & No control group & 1 and 2 & Switzerland & {$[228]$} \\
\hline NCT04572412 & N/A & $50 \mathrm{cGy}$ & Depends $\left(^{\wedge}\right)$ & 13 & No control group & 1 & UK & {$[229,230]$} \\
\hline NCT04377477 & COLOR-19 & 70 cGy & Single & 30 & No control group & 2 & Italy & [231] \\
\hline NCT04420390 & LOWRAD-COV19 & $\leq 1 \mathrm{~Gy}$ & Single & 41 & No control group & $\mathrm{N} / \mathrm{A}$ & Spain & [232] \\
\hline NCT04380818 & N/A & $0.5 \mathrm{~Gy}$ & Depends (\&) & 106 & Not radiotherapy & 1 and 2 & Spain & {$[233,234]$} \\
\hline NCT04904783 & LOCORAD & $0.5 \mathrm{~Gy}$ & Single & 20 & Not radiotherapy & N/A & India & [235] \\
\hline
\end{tabular}

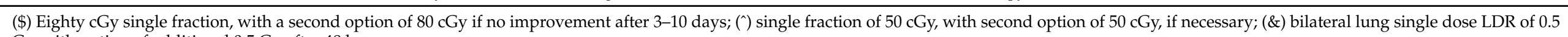
Gy, with option of additional 0.5 Gy after $48 \mathrm{~h}$. 
Whereas reports show attenuation of COVID-19 symptoms with relatively low-dose radiotherapy, scientific and public concerns about long-term side effects are evident. There is worry that radiation exposure will induce long-term adverse outcomes, including bystander effects, oxidative stress, chronic inflammatory responses, cytotoxicity, genomic instability, and ultimately cancer and degenerative conditions [202,236]. In particular, current regulatory guidelines are based on a linear no-threshold (LNT) model that assumes exposure to any dose of ionizing radiation increases cancer risk. The LNT model is a practical operational framework used in radiation protection to ensure the safety of workers and members of the public, which includes those who are particularly vulnerable to the effects of ionizing radiation. However, from the point of view of risk assessment, several studies claim beneficial effects from low-dose radiation (reviewed in $[237,238]$ ) and show that lowdose radiation effects often differ from those induced by high-dose radiation, at least in the case of the low-linear-energy transfer types of radiation such as $X$ and $\gamma$ rays $[239,240]$. These studies reveal that in vitro exposure of cells maintained in culture and in vivo exposure of rodents to low doses of sparsely ionizing radiation (i.e., $X$ and $\gamma$ rays) modulate changes at the molecular level, and provide significant evidence supporting up-regulation of DNA repair, anti-oxidation, and expression of adaptive responses [202,241].

With respect to treatment for COVID-19, low-dose radiotherapy may have unique advantages emerging from its successful history in treating inflammatory diseases and unresolved pneumonia:

1. Low-dose radiotherapy can target inflamed areas such as the lung specifically, whereas antiviral, anti-inflammatory drugs, and statins are systemic drugs that affect the whole body.

2. The benefits of low-dose radiotherapy appear to outweigh the risk of long-term effects in the case of seriously ill COVID-19 patients.

3. Low-dose radiotherapy is less likely to induce drug-resistant mutation in the virus compared to anti-viral drugs [242].

It is generally accepted that radiation is a mild mutagen [243]. As an RNA virus, SARS-CoV-2 is characterized by a moderate to high mutation rate. Mutation hot spots have been identified during the current pandemic, indicating potential drug resistance [109]. Antiviral drugs, the research topic granted the 2018 Nobel Prize in Chemistry (for phage display) demonstrated that therapeutic protein engineering can be modified under selective pressure, to target viruses [244]. Conversely, based on the reaction of viruses to antiviral drugs, a more resistant group of viruses might be selected under target drug therapies.

Low-dose radiotherapy is a cost-effective treatment that is available in most hospitals. In contrast, the expense for molecular-targeting therapies is challenging for a large number of patients in both developed and developing countries. Considering economic reasons, it may be argued that low-dose radiotherapy would reach more patients than targeted therapies and with a reduced financial burden. In this context, portable low-dose radiation systems for bedside treatment, in ICU, of critically ill COVID-19 patients would be advantageous [245]. Such devices have the added benefit of keeping COVID-19 patients separate from other patients, especially vulnerable patients receiving radiation therapy in the same hospital, thereby minimizing the probability of infection [245].

\section{Discussion}

Although the clinical outcomes of low-dose radiotherapy for COVID-19 patients are promising, the specific mechanisms for its immunomodulatory effects remain unclear. Various mechanisms may be involved in reducing inflammation by ionizing radiation, including the induction of apoptosis in immune cells, secretion of anti-inflammatory factors, and the reduced function of macrophages [246]. To further elucidate the underlying mechanisms, in vitro studies may apply strategies to induce molecular modifications in cells interacting with the coronavirus. Furthermore, low-dose radiotherapy may induce alterations in the immune microenvironment. Using flow cytometry, identification of molecular markers on immune cells as well as other cells impacted by the virus upon 
irradiation might be informative. It will also be interesting to study whether apoptosis of cytokine-producing infiltrating cells is a substantial component, as a fast response in COVID-19 patients was noticed after low-dose radiotherapy [241]. It has been recognized that low-dose radiotherapy does not induce post-treatment pancytopenia or immunosuppression, which implies that low-dose radiotherapy might not worsen immune activation or slow viral clearance [216]. This proposed idea may be tested by applying low-dose radiotherapy on pseudovirus-infected cells that are co-cultured with immune cells, and by comparing the spectrum of changes in cell surface biomarkers by flow cytometry, as well as the speed of viral clearance by live-cell imaging using confocal microscopy. Specifically, qPCR or sequencing technology may be applied to analyze gene expression during the interaction between immune cells and viral particles. This may shed further light on the molecular pathways associated with healthy cells fighting a viral attack.

There is a concern that the anti-inflammatory effect of low-dose radiotherapy may not be strong enough to inhibit the cytokine storm [241]. To elucidate the mechanisms for further application, low-dose radiotherapy may be combined with FDA-approved anti-inflammatory drugs, molecular-targeting drugs, and anti-viral drugs, such as dexamethasone, baricitinib, and remdesivir $[139,143,247]$. If the combined therapy shows an additive effect at the cellular level, verifying the effect in animal studies is essential before obtaining approval for eventual administration to patients in serious conditions. It will be interesting to explore whether low-dose radiotherapy would improve the effectiveness of those top candidates for targeted treatment.

With respect to the concerns about adverse effects of radiation exposure, different dosages may be applied to determine the minimum therapeutic dose level that can be effective in relieving inflammation, and whether the radiation dose should be delivered as a single bolus or be fractionated. Many confounders may bias and limit the result regarding the long-term effect of low-dose radiotherapy on humans. Considering that not enough studies of low-dose radiotherapy are available on animal models, Prasanna et al. indicated that additional pre-clinical studies in non-human primates, hamsters, or mice are required before proceeding with low-dose radiation therapy in COVID-19 patients [201]. Hence, in vivo experiments using different animal models are necessary to understand the variables associated with radiation delivery (i.e., dose, dose-rate, fractionation) on attenuating inflammation [201]. The use of low-dose radiation as an adjuvant therapy was recommended by others, opening more avenue for multi-modal therapy for severe COVID patients [248]. With suitable experimental models, various parameters can be optimized for beneficial clinical effects [248].

In alignment with Schaue's opinion, it is critical—although tricky—to identify the patients who are likely to benefit from radiation treatment and to set the time point early enough for them to receive treatment and recover [203]. Theoretically, the patients with a clinical and radiological diagnosis of severe bilateral interstitial pneumonia might benefit from low-dose radiation to the lungs. Dr. Jian-Jian Li, who advocated low-dose radiotherapy early in the COVID-19 pandemic, suggested the necessity of precise evaluation of the potential effects of low-dose radiation in control of the cytokine storm and ARDS, as well as the proper timing and dosage using animal models [207]. By identifying biomarkers associated with relief of the cytokine storm by low-dose radiation, and by comparing their correlation with clinical laboratory results, it becomes possible to provide a checklist of critical markers to triage patients when they first step into the hospital. Those who might develop severe disease and might benefit most with the least risk from low-dose radiotherapy can get immediate treatment and avoid deterioration of their condition. If pandemics are inevitable, by expanding research on therapeutic avenues for COVID-19 and understating the underlying mechanisms, we may become better prepared to defend against other novel viral infection.

Supplementary Materials: The following are available online at https:/ /www.mdpi.com/article/10 $.3390 /$ cells10092212/s1. Table S1: The development of COVID-19 vaccines in clinical trials (adjusted from WHO document) [151]. 
Author Contributions: J.Y. prepared the original draft; Y.W., E.I.A. and A.B.J. reviewed and edited the manuscript; Y.W. acquired the funding. All authors have read and agreed to the published version of the manuscript.

Funding: Funding and support for the research was provided by a Federal Nuclear Science and Technology Work Plan of the Atomic Energy of Canada Limited.

Institutional Review Board Statement: Not applicable.

Informed Consent Statement: Not applicable.

Data Availability Statement: Data source for Figure 1: https:/ / data.cdc.gov/NCHS / ProvisionalCOVID-19-Death-Counts-by-Week-Ending-D/r8kw-7aab (accessed on 23 August 2021). Data source for Figure 4: Remdesivir for the Treatment of COVID-19-Final Report [139], Baricitinib plus Remdesivir for Hospitalized Adults with COVID-19 [143].

Acknowledgments: Funding and support for the research were provided by a Federal Nuclear Science and Technology Work Plan of the Atomic Energy of Canada Limited. J.Y. especially thanks Hongbing $\mathrm{Yu}$ for reviewing the first draft and providing precious suggestions and encouragement.

Conflicts of Interest: The authors declare no conflict of interest. The funders had no role in the design of the study, in the collection, analyses, or interpretation of data; in the writing of the manuscript, or in the decision to publish the results.

\section{References}

1. Worldometers. COVID-19 Coronavirus Pandemic. 2021. Available online: https://www.worldometers.info/coronavirus/ (accessed on 26 April 2021).

2. Bendavid, E.; Oh, C.; Bhattacharya, J.; Ioannidis, J.P.A. Assessing mandatory stay-at-home and business closure effects on the spread of COVID-19. Eur. J. Clin. Investig. 2021, 51, e13484. [CrossRef]

3. Zamir, M.; Shah, Z.; Nadeem, F.; Memood, A.; Alrabaiah, H.; Kumam, P. Non Pharmaceutical Interventions for Optimal Control of COVID-19. Comput. Methods Programs Biomed. 2020, 196, 105642. [CrossRef] [PubMed]

4. Canada.ca. COVID-19: Main Modes of Transmission. 2020. Available online: https://www.canada.ca/en/public-health/services/ diseases/2019-novel-coronavirus-infection/health-professionals/main-modes-transmission.html\#shr-pg0 (accessed on 26 April 2021).

5. Peng, Y.; Zhou, Y.H. Coronavirus Disease (COVID-19): How Is It Transmitted? J. Med. Virol. 2020, 92, 1408-1409. [CrossRef]

6. COVID-19: Epidemiology, Virology and Clinical Features. Available online: https://www.gov.uk/government/publications/ wuhan-novel-coronavirus-background-information/wuhan-novel-coronavirus-epidemiology-virology-and-clinical-features (accessed on 12 March 2021).

7. Gorbalenya, A.E.; Baker, S.C.; Baric, R.S.; De Groot, R.J.; Drosten, C.; Gulyaeva, A.A.; Haagmans, B.L.; Lauber, C.; Leontovich, A.M.; Neuman, B.W.; et al. Severe acute respiratory syndrome-related coronavirus: The species and its viruses-A statement of the Coronavirus Study Group. bioRxiv 2020. preprint.

8. Wu, Y.; Ho, W.; Huang, Y.; Jin, D.-Y.; Li, S.; Liu, S.-L.; Liu, X.; Qiu, J.; Sang, Y.; Wang, Q.; et al. SARS-CoV-2 is an appropriate name for the new coronavirus. Lancet 2020, 395, 949-950. [CrossRef]

9. Graham, R.L.; Donaldson, E.F.; Baric, R.S. A decade after SARS: Strategies for controlling emerging coronaviruses. Nat. Rev. Genet. 2013, 11, 836-848. [CrossRef] [PubMed]

10. Centers of Disease Control and Prevention. Influenza (Flu) Past Seasons. Available online: https://www.cdc.gov/flu/season/ index.html (accessed on 23 July 2021).

11. Faust, J.S.; Rio, C.D. Assessment of Deaths from COVID-19 and From Seasonal Influenza. Am. Med. Assoc. 2020, 180, 1045-1046. [CrossRef]

12. National Center for Farmworker Health (Ed.) Provisional COVID-19 Death Counts by Week Ending Date and State. Available online: https://data.cdc.gov/NCHS/Provisional-COVID-19-Death-Counts-by-Week-Ending-D/r8kw-7aab (accessed on 2 August 2021).

13. Konala, V.M.; Adapa, S.; Naramala, S.; Chenna, A.; Lamichhane, S.; Garlapati, P.R.; Balla, M.; Gayam, V. A Case Series of Patients Coinfected with Influenza and COVID-19. J. Investig. Med. High Impact Case Rep. 2020, 8, 1-7. [CrossRef] [PubMed]

14. Wang, Y.; Ao, G.; Qi, X.; Xie, B. The association between COVID-19 and asthma: A systematic review and meta-analysis. Clin. Exp. Allergy 2020, 50, 1274-1277. [CrossRef]

15. Mendes, N.F.; Jara, C.P.; Mansour, E.; Araújo, E.P.; Velloso, L.A. Asthma and COVID-19: A systematic review. Allergy Asthma Clin. Immunol. 2021, 17, 1-12. [CrossRef]

16. Eger, K.; Bel, E.H. Asthma and COVID-19: Do we finally have answers? Eur. Respir. J. 2020, 57, 2004451. [CrossRef] [PubMed]

17. COVID-19 Rapid Guideline: Dermatological Conditions Treated with Drugs Affecting the Immune Response; NICE Guideline: London, UK, 2020.

18. Group, B.P. Management of Coexisting Conditions in the Context of COVID-19; BMJ Publishing: London, UK, 2020. 
19. NICE Guideline. COVID-19 Rapid Guideline: Gastrointestinal and Liver Conditions Treated with Drugs Affecting the Immune Response. Available online: https:/ / www.nice.org.uk/guidance/ng172 (accessed on 25 January 2021).

20. Leung, J.M.; Niikura, M.; Yang, C.W.T.; Sin, D.D. COVID-19 and COPD. Eur. Respir. J. 2020, 56, 2002108. [CrossRef]

21. Guan, W.-J.; Liang, W.-H.; Zhao, Y.; Liang, H.-R.; Chen, Z.-S.; Li, Y.-M.; Liu, X.-Q.; Chen, R.-C.; Tang, C.-L.; Wang, T.; et al. Comorbidity and its impact on 1590 patients with COVID-19 in China: A nationwide analysis. Eur. Respir. J. 2020, 55, 2000547. [CrossRef] [PubMed]

22. Sin, D.D. COVID-19 in COPD: A growing concern. EClinicalMedicine 2020, 26, 100546. [CrossRef]

23. ESMO. Cancer Patient Management during the COVID-19 Pandemic. Available online: https://www.esmo.org/guidelines/ cancer-patient-management-during-the-covid-19-pandemic/disclaimer (accessed on 25 January 2021).

24. Ejaz, H.; Alsrhani, A.; Zafar, A.; Javed, H.; Junaid, K.; Abdalla, A.E.; Abosalif, K.O.; Ahmed, Z.; Younas, S. COVID-19 and comorbidities: Deleterious impact on infected patients. J. Infect. Public Health 2020, 13, 1833-1839. [CrossRef]

25. Sypmtoms of COVD-19. Available online: https://www.cdc.gov/coronavirus/2019-ncov/symptoms-testing/symptoms.html (accessed on 2 August 2021).

26. Grant, M.C.; Geoghegan, L.; Arbyn, M.; Mohammed, Z.; McGuinness, L.; Clarke, E.L.; Wade, R.G. The prevalence of symptoms in 24,410 adults infected by the novel coronavirus (SARS-CoV-2; COVID-19): A systematic review and meta-analysis of 148 studies from 9 countries. PLoS ONE 2020, 15, e0234765. [CrossRef]

27. Armitage, M. How Do COVID-19's Annual Deaths and Mortality Rate Compare to the Flu's? Available online: https://www. goodrx.com/blog/flu-vs-coronavirus-mortality-and-death-rates-by-year / (accessed on 3 July 2021).

28. Bénézit, F.; Le Turnier, P.; Declerck, C.; Paillé, C.; Revest, M.; Dubée, V.; Tattevin, P.; Arvieux, C.; Baldeyrou, M.; Chapplain, J.-M.; et al. Utility of hyposmia and hypogeusia for the diagnosis of COVID-19. Lancet Infect. Dis. 2020, 20, 1014-1015. [CrossRef]

29. Stone, J. There's an Unexpected Loss of Smell and Taste in Coronavirus Patients. Available online: https://www.forbes.com/sites / judystone/2020/03/20/theres-an-unexpected-loss-of-smell-and-taste-in-coronavirus-patients /?sh=549123bd5101 (accessed on 2 August 2021).

30. Gautier, J.; Ravussin, Y. A New Symptom of COVID-19: Loss of Taste and Smell. Obesity 2020, 28, 848. [CrossRef] [PubMed]

31. Struyf, T.; Deeks, J.J.; Dinnes, J.; Takwoingi, Y.; Davenport, C.; Leeflang, M.M.; Spijker, R.; Hooft, L.; Emperador, D.; Dittrich, S.; et al. Signs and symptoms to determine if a patient presenting in primary care or hospital outpatient settings has COVID-19 disease. Cochrane Database Syst. Rev. 2020, 2020, CD013665. [CrossRef]

32. Jawerth, N. How Is the COVID-19 Virus Detected Using Real Time RT-PCR? Available online: https://www.iaea.org/newscenter/ news / how-is-the-covid-19-virus-detected-using-real-time-rt-pcr (accessed on 25 January 2021).

33. Centers of Disease Control and Prevention. Test for COVID-19 Only. Available online: https://www.cdc.gov/coronavirus/2019 -ncov / lab/virus-requests.html (accessed on 25 January 2021).

34. World Health Organization. Molecular Assays to Diagnose COVID-19: Summary Table of Available Protocols. Available online: https:/ / www.who.int/publications/m/item/molecular-assays-to-diagnose-covid-19-summary-table-of-available-protocols (accessed on 26 January 2021).

35. Centers for Disease Control and Prevention. Specimen Collection. 2020. Available online: https://www.cdc.gov/coronavirus/20 19-nCoV/lab/guidelines-clinical-specimens.html (accessed on 25 January 2021).

36. Ai, T.; Yang, Z.; Hou, H.; Zhan, C.; Chen, C.; Lv, W.; Tao, Q.; Sun, Z.; Xia, L. Correlation of Chest CT and RT-PCR Testing for Coronavirus Disease 2019 (COVID-19) in China: A Report of 1014 Cases. Radiology 2020, 296, E32-E40. [CrossRef] [PubMed]

37. Chung, M.; Bernheim, A.; Mei, X.; Zhang, N.; Huang, M.; Zeng, X.; Cui, J.; Xu, W.; Yang, Y.; Fayad, Z.A.; et al. CT Imaging Features of 2019 Novel Coronavirus (2019-nCoV). Radiology 2020, 295, 202-207. [CrossRef]

38. Xu, B.; Xing, Y.; Peng, J.; Zheng, Z.; Tang, W.; Sun, Y.; Xu, C.; Peng, F. Chest CT for detecting COVID-19: A systematic review and meta-analysis of diagnostic accuracy. Eur. Radiol. 2020, 30, 5720-5727. [CrossRef] [PubMed]

39. Li, Y.; Xia, L. Coronavirus Disease 2019 (COVID-19): Role of Chest CT in Diagnosis and Management. Am. J. Roentgenol. 2020, 214, 1280-1286. [CrossRef]

40. ACR. ACR Recommendations for the Use of Chest Radiography and Computed Tomography (CT) for Suspected COVID-19 Infection. Available online: https:/ / www.acr.org/Advocacy-and-Economics/ACR-Position-Statements/Recommendationsfor-Chest-Radiography-and-CT-for-Suspected-COVID19-Infection (accessed on 25 January 2021).

41. Pereira, A. Long-Term Neurological Threats of COVID-19: A Call to Update the Thinking about the Outcomes of the Coronavirus Pandemic. Front. Neurol. 2020, 11, 308. [CrossRef] [PubMed]

42. Bansal, M. Cardiovascular Disease and COVID-19. Diabetes Metab. Syndr. Clin. Res. Rev. 2020, 14, 247-250. [CrossRef]

43. Armitage, M. COVID-19 Symptoms vs. Flu Symptoms: How Are They Different? Available online: https://www.goodrx.com/ blog/flu-symptoms-vs-coronavirus-symptoms-and-signs / (accessed on 25 January 2021).

44. Douglas, M.; Katikireddi, S.V.; Taulbut, M.; McKee, M.; McCartney, G. Mitigating the wider health effects of covid-19 pandemic response. BMJ 2020, 369, m1557. [CrossRef]

45. WHO. Coronavirus Disease (COVID-19): Similarities and Differences with Influenza. Available online: https://www.who.int/ news-room / q-a-detail/ coronavirus-disease-covid-19-similarities-and-differences-with-influenza\#: \{\}:text=For\%20COVID\% 2D19\%2C,observed\%20for\%20influenza\%20infection (accessed on 16 March 2021). 
46. Wang, D.; Hu, B.; Hu, C.; Zhu, F.; Liu, X.; Zhang, J.; Wang, B.; Xiang, H.; Cheng, Z.; Xiong, Y.; et al. Clinical Characteristics of 138 Hospitalized Patients With 2019 Novel Coronavirus-Infected Pneumonia inWuhan, China. J. Am. Med. Assoc. 2020, 323, 1061-1069. [CrossRef] [PubMed]

47. Huang, C.; Wang, Y.; Li, X.; Ren, L.; Zhao, J.; Hu, Y.; Zhang, L.; Fan, G.; Xu, J.; Gu, X.; et al. Clinical features of patients infected with 2019 novel coronavirus in Wuhan, China. Lancet 2020, 395, 497-506. [CrossRef]

48. Murthy, S.; Gomersall, C.D.; Fowler, R.A. Care for Critically Ill PatientsWith COVID-19. J. Am. Med. Assoc. 2020, 323, 315. [CrossRef]

49. Chen, N.; Zhou, M.; Dong, X.; Qu, J.; Gong, F.; Han, Y.; Qiu, Y.; Wang, J.; Liu, Y.; Wei, Y.; et al. Epidemiological and clinical characteristics of 99 cases of 2019 novel coronavirus pneumonia in Wuhan, China: A descriptive study. Lancet 2020, 395, 507-513. [CrossRef]

50. Coronavirus Disease (COVID-19): For Health Professionals. Available online: https://www.canada.ca/en/public-health/ services/diseases/2019-novel-coronavirus-infection/health-professionals.html (accessed on 16 March 2021).

51. Viceconte, G.; Petrosillo, N. COVID-19 R0: Magic Number or Conundrum? Infect. Dis. Rep. 2020, 12, 1-2. [CrossRef]

52. Heesterbeek, J. A Brief History of R0 and a Recipe for its Calculation. Acta Biotheor. 2002, 50, 189-204. [CrossRef] [PubMed]

53. Dietz, K. The estimation of the basic reproduction number for infectious diseases. Stat. Methods Med. Res. 1993, 2, 23-41. [CrossRef]

54. Fine, P.E.M. Herd Immunity: History, Theory, Practice. Epidemiol. Rev. 1993, 15, 265-302. [CrossRef] [PubMed]

55. Diekmann, O.; Heesterbeek, J.A.P.; Metz, J.A.J. On the definition and the computation of the basic reproduction ratio R 0 in models for infectious diseases in heterogeneous populations. J. Math. Biol. 1990, 28, 365-382. [CrossRef] [PubMed]

56. Delamater, P.L.; Street, E.J.; Leslie, T.F.; Yang, Y.T.; Jacobsen, K.H. Complexity of the Basic Reproduction Number (R0). Emerg. Infect. Dis. 2019, 25, 1-4. [CrossRef]

57. Bates, V. What Is R0? Gauging Contagious Infections. 2020. Available online: https://www.healthline.com/health/r-noughtreproduction-number (accessed on 26 January 2021).

58. Dropkin, G. COVID-19 UK Lockdown Forecasts and R0. Front. Public Health 2020, 8, 256. [CrossRef]

59. Samui, P.; Mondal, J.; Khajanchi, S. A mathematical model for COVID-19 transmission dynamics with a case study of India. Chaos Solitons Fractals 2020, 140, 110173. [CrossRef]

60. Temime, L.; Gustin, M.-P.; Duval, A.; Buetti, N.; Crépey, P.; Guillemot, D.; Thiébaut, R.; Vanhems, P.; Zahar, J.-R.; Smith, D.R.M.; et al. A Conceptual Discussion about the Basic Reproduction Number of Severe Acute Respiratory Syndrome Coronavirus 2 in Healthcare Settings. Clin. Infect. Dis. 2020, 72, 141-143. [CrossRef]

61. Wei, Y.Y.; Guan, J.X.; Zhao, Y.; Shen, S.P.; Chen, F. Inference of start time of resurgent COVID-19 epidemic in Beijing with SEIR dynamics model and evaluation of control measure effect. Zhonghua Liu Xing Bing Xue Za Zhi 2020, 41, 1772-1776. [CrossRef]

62. Khan, I.M.; Haque, U.; Zhang, W.; Zafar, S.; Wang, Y.; He, J.; Sun, H.; Lubinda, J.; Rahman, M.S. COVID-19 in China: Risk Factors and R0 Revisited. Acta Trop. 2020, 213, 105731. [CrossRef] [PubMed]

63. COVID-19-A Global Pandemic; WHO: Geneva, Switzerland, 2020; Available online: who.int (accessed on 27 January 2021).

64. Zhao, S.; Lin, Q.; Ran, J.; Musa, S.S.; Yang, G.; Wang, W.; Lou, Y.; Gao, D.; Yang, L.; He, D.; et al. Preliminary estimation of the basic reproduction number of novel coronavirus (2019-nCoV) in China, from 2019 to 2020: A data-driven analysis in the early phase of the outbreak. Int. J. Infect. Dis. 2020, 92, 214-217. [CrossRef] [PubMed]

65. Prem, K.; Liu, Y.; Russell, T.W.; Kucharski, A.J.; Eggo, R.M.; Davies, N.; Jit, M.; Klepac, P.; Flasche, S.; Clifford, S.; et al. The effect of control strategies to reduce social mixing on outcomes of the COVID-19 epidemic in Wuhan, China: A modelling study. Lancet Public Health 2020, 5, e261-e270. [CrossRef]

66. Furukawa, N.W.; Brooks, J.T.; Sobel, J. Evidence Supporting Transmission of Severe Acute Respiratory Syndrome Coronavirus 2 While Presymptomatic or Asymptomatic. Emerg. Infect. Dis. 2020, 26, e201595. [CrossRef]

67. Du, Z.; Xu, X.; Wu, Y.; Wang, L.; Cowling, B.J.; Meyers, L.A. Serial Interval of COVID-19 among Publicly Reported Confirmed Cases. Emerg. Infect. Dis. 2020, 26, 1341-1343. [CrossRef] [PubMed]

68. Ferretti, L.; Wymant, C.; Kendall, M.; Zhao, L.; Nurtay, A.; Abeler-Dörner, L.; Parker, M.; Bonsall, D.; Fraser, C. Quantifying SARS-CoV-2 transmission suggests epidemic control with digital contact tracing. Science 2020, 368, eabb6936. [CrossRef]

69. Savvides, C.; Siegel, R. Asymptomatic and presymptomatic transmission of SARS-CoV-2: A systematic review. medRxiv 2020, 2. preprint. [CrossRef]

70. Susswein, Z.; Bansal, S. Characterizing superspreading of SARS-CoV-2: From mechanism to measurement. medRxiv 2020. preprint.

71. Tillett, R.L.; Sevinsky, J.R.; Hartley, P.D.; Kerwin, H.; Crawford, N.; Gorzalski, A.; Laverdure, C.; Verma, S.C.; Rossetto, C.C.; Jackson, D. Genomic evidence for reinfection with SARS-CoV-2: A case study. Lancet Infect Dis. 2020, 21, 52-58. [CrossRef]

72. Vrieze, J.D. More People Are Getting COVID-19 Twice, Suggesting Immunity Wanes Quickly in Some. Available online: https:// www.sciencemag.org/news/2020/11/more-people-are-getting-covid-19-twice-suggesting-immunity-wanes-quickly-some (accessed on 16 March 2021).

73. Gaebler, C.; Wang, Z.; Lorenzi, J.C.C.; Muecksch, F.; Finkin, S.; Tokuyama, M.; Cho, A.; Jankovic, M.; Schaefer-Babajew, D.; Oliveira, T.Y.; et al. Evolution of antibody immunity to SARS-CoV-2. Nature 2021, 383, 1544-1555. [CrossRef]

74. Almeida, J.D.; Berry, D.M.; Cunningham, C.H.; Hamre, D.; Hofstad, M.S.; Mallucci, L.; McIntosh, K.; Tyrrell, D.A.J. Virology: Coronaviruses. Nature 1968, 220, 5650 . 
75. Coronavirinae. ViralZone. Available online: https://en.wikipedia.org/wiki/Coronaviridae (accessed on 16 March 2021).

76. Fan, Y.; Zhao, K.; Shi, Z.-L.; Zhou, P. Bat Coronaviruses in China. Viruses 2019, 11, 210. [CrossRef]

77. Lai, M.M.; Cavanagh, D. The Molecular Biology of Coronaviruses. Adv. Virus Res. 1997, 48, 193-292. [CrossRef]

78. Bárcena, M.; Oostergetel, G.T.; Bartelink, W.; Faas, F.G.A.; Verkleij, A.; Rottier, P.J.M.; Koster, A.J.; Bosch, B.J. Cryo-electron tomography of mouse hepatitis virus: Insights into the structure of the coronavirion. Proc. Natl. Acad. Sci. USA 2009, 106, 582-587. [CrossRef] [PubMed]

79. Glaunsinger, B. Coronaviruses 101: Focus on Molecular Virology. 2020. Available online: youtube.com (accessed on 29 January 2021).

80. Zhou, P.; Yang, X.-L.; Wang, X.-G.; Hu, B.; Zhang, L.; Zhang, W.; Si, H.-R.; Zhu, Y.; Li, B.; Huang, C.-L.; et al. A pneumonia outbreak associated with a new coronavirus of probable bat origin. Nature 2020, 579, 270-273. [CrossRef] [PubMed]

81. Hoffmann, M.; Kleine-Webe, H.; Krüger, N.; Müller, M.; Drosten, C.; Pöhlmann, S. The novel coronavirus 2019 (2019-nCoV) uses the SARS-coronavirus receptor ACE2 and the cellular protease TMPRSS2 for entry into target cells. bioRxiv 2020. preprint. [CrossRef]

82. Tai, W.; He, L.; Zhang, X.; Pu, J.; Voronin, D.; Jiang, S.; Zhou, Y.; Du, L. Characterization of the receptor-binding domain (RBD) of 2019 novel coronavirus: Implication for development of RBD protein as a viral attachment inhibitor and vaccine. Cell. Mol. Immunol. 2020, 17, 613-620. [CrossRef]

83. Walls, A.C.; Park, Y.-J.; TortoricI, M.A.; Wall, A.; McGuire, A.T.; Veesler, D. Structure, Function, and Antigenicity of the SARS-CoV-2 Spike Glycoprotein. Cell 2020, 180, 281-292. [CrossRef]

84. Chan, J.F.-W.; Yuan, S.; Kok, K.-H.; To, K.K.-W.; Chu, H.; Yang, J.; Xing, F.; Liu, J.; Yip, C.C.-Y.; Poon, R.W.-S.; et al. A familial cluster of pneumonia associated with the 2019 novel coronavirus indicating person-to-person transmission: A study of a family cluster. Lancet 2020, 395, 514-523. [CrossRef]

85. Wrapp, D.; Wang, N.; Corbett, K.S.; Goldsmith, J.A.; Hsieh, C.-L.; Abiona, O.; Graham, B.S.; McLellan, J.S. Cryo-EM structure of the 2019-nCoV spike in the prefusion conformation. Science 2020, 367, 1260-1263. [CrossRef]

86. Lan, J.; Ge, J.; Yu, J.; Shan, S.; Zhou, H.; Fan, S.; Zhang, Q.; Shi, X.; Wang, Q.; Zhang, L.; et al. Structure of the SARS-CoV-2 spike receptor-binding domain bound to the ACE2 receptor. Nature 2020, 581, 215-220. [CrossRef] [PubMed]

87. Cantuti-Castelvetri, L.; Ojha, R.; Pedro, L.D.; Djannatian, M.; Franz, J.; Kuivanen, S.; Van Der Meer, F.; Kallio, K.; Kaya, T.; Anastasina, M.; et al. Neuropilin-1 facilitates SARS-CoV-2 cell entry and infectivity. Science 2020, 370, 856-860. [CrossRef] [PubMed]

88. Daly, J.L.; Simonetti, B.; Klein, K.; Chen, K.-E.; Williamson, M.K.; Antón-Plágaro, C.; Shoemark, D.K.; Simón-Gracia, L.; Bauer, M.; Hollandi, R.; et al. Neuropilin-1 is a host factor for SARS-CoV-2 infection. Science 2020, 370, 861-865. [CrossRef]

89. Wang, S.; Qiu, Z.; Hou, Y.; Deng, X.; Xu, W.; Zheng, T.; Wu, P.; Xie, S.; Bian, W.; Zhang, C.; et al. AXL is a candidate receptor for SARS-CoV-2 that promotes infection of pulmonary and bronchial epithelial cells. Cell Res. 2021, 31, 126-140. [CrossRef] [PubMed]

90. Bohan, D.; Ert, H.V.; Ruggio, N.; Rogers, K.J.; Badreddine, M.; Aguilar Briseno, J.A.; Rojas Chavez, R.A.; Gao, B.; Stokowy, T.; Christakou, E.; et al. Phosphatidylserine Receptors Enhance SARS-CoV-2 Infection: AXL as a Therapeutic Target for COVID-19. bioRxiv 2021. preprint. [CrossRef]

91. Astuti, I. Ysrafil Severe Acute Respiratory Syndrome Coronavirus 2 (SARS-CoV-2): An overview of viral structure and host response. Diabetes Metab. Syndr. Clin. Res. Rev. 2020, 14, 407-412. [CrossRef] [PubMed]

92. Gui, M.; Song, W.; Zhou, H.; Xu, J.; Chen, S.; Xiang, Y.; Wang, X. Cryo-electron microscopy structures of the SARS-CoV spike glycoprotein reveal a prerequisite conformational state for receptor binding. Cell Res. 2016, 27, 119-129. [CrossRef]

93. Song, W.; Gui, M.; Wang, X.; Xiang, Y. Cryo-EM structure of the SARS coronavirus spike glycoprotein in complex with its host cell receptor ACE2. PLoS Pathog. 2018, 14, e1007236. [CrossRef]

94. Kirchdoerfer, R.N.; Wang, N.; Pallesen, J.; Wrapp, D.; Turner, H.L.; Cottrell, C.A.; Corbett, K.S.; Graham, B.S.; McLellan, J.S.; Ward, A.B. Stabilized coronavirus spikes are resistant to conformational changes induced by receptor recognition or proteolysis. Sci. Rep. 2018, 8, 1-11, Corrected in 2018, 8, 1. [CrossRef]

95. Bosch, B.J.; Van der Zee, R.; De Haan, C.A.; Rottier, P.J.M. The Coronavirus Spike Protein Is a Class I Virus Fusion Protein: Structural and Functional Characterization of the Fusion Core Complex. J. Virol. 2003, 77, 8801-8811. [CrossRef]

96. Rathore, J.S.; Ghosh, C. Severe acute respiratory syndrome coronavirus-2 (SARS-CoV-2), a newly emerged pathogen: An overview. Pathog. Dis. 2020, 78, ftaa042. [CrossRef] [PubMed]

97. Lu, R.; Zhao, X.; Li, J.; Niu, P.; Yang, B.; Wu, H.; Wang, W.; Song, H.; Huang, B.; Zhu, N.; et al. Genomic characterisation and epidemiology of 2019 novel coronavirus: Implications for virus origins and receptor binding. Lancet 2020, 395, 565-574. [CrossRef]

98. Wan, Y.; Shang, J.; Graham, R.; Baric, R.S.; Li, F. Receptor Recognition by the Novel Coronavirus from Wuhan: An Analysis Based on Decade-Long Structural Studies of SARS Coronavirus. J. Virol. 2020, 94, 00127-20. [CrossRef]

99. Atlas, T.H.P. ACE2. Available online: proteinatlas.org (accessed on 19 February 2021).

100. Rabi, F.A.; Al Zoubi, M.S.; Kasasbeh, G.A.; Salameh, D.M.; Al-Nasser, A.D. SARS-CoV-2 and Coronavirus Disease 2019: What We Know So Far. Pathogens 2020, 9, 231. [CrossRef] [PubMed]

101. Glowacka, I.; Bertram, S.; Müller, M.A.; Allen, P.D.; Soilleux, E.J.; Pfefferle, S.; Steffen, I.; Tsegaye, T.S.; He, Y.; Gnirss, K.; et al. Evidence that TMPRSS2 Activates the Severe Acute Respiratory Syndrome Coronavirus Spike Protein for Membrane Fusion and Reduces Viral Control by the Humoral Immune Response. J. Virol. 2011, 85, 4122-4134. [CrossRef] [PubMed] 
102. Andersen, K.G.; Rambaut, A.; Lipkin, W.I.; Holmes, E.C.; Garry, R.F. The proximal origin of SARS-CoV-2. Nat. Med. 2020, 26, 450-452. [CrossRef]

103. Hoffmann, M.; Kleine-Weber, H.; Pöhlmann, S. A Multibasic Cleavage Site in the Spike Protein of SARS-CoV-2 Is Essential for Infection of Human Lung Cells. Mol. Cell 2020, 78, 779-784.e5. [CrossRef]

104. Tortorici, M.A.; Veesler, D. Structural insights into coronavirus entry. Adv. Virus Res. 2019, 105, 93-116. [CrossRef]

105. Centers of Disease Control and Prevention. Genomic Surveillance for SARS-CoV-2. Available online: https:/ /www.cdc.gov/ coronavirus/2019-ncov/cases-updates/variant-surveillance.html (accessed on 22 February 2021).

106. Korber, B.; Fischer, W.M.; Gnanakaran, S.; Yoon, H.; Theiler, J.; Abfalterer, W.; Hengartner, N.; Giorgi, E.E.; Bhattacharya, T.; Foley, B.; et al. Tracking Changes in SARS-CoV-2 Spike: Evidence that D614G Increases Infectivity of the COVID-19 Virus. Cell 2020, 182, 812-827.e19. [CrossRef]

107. Volz, E.; Hill, V.; McCrone, J.T.; Price, A.; Jorgensen, D.; O’Toole, A.; Southgate, J.; Johnson, R.; Jackson, B.; Nascimento, F.F.; et al. Evaluating the Effects of SARS-CoV-2 Spike Mutation D614G on Transmissibility and Pathogenicity. Cell 2021, 184, 64-75.e11. [CrossRef]

108. Lauring, A.S.; Hodcroft, E.B. Genetic Variants of SARS-CoV-2-What Do They Mean? JAMA 2021, 325, 529-531. [CrossRef]

109. Pachetti, M.; Marini, B.; Benedetti, F.; Giudici, F.; Mauro, E.; Storici, P.; Masciovecchio, C.; Angeletti, S.; Ciccozzi, M.; Gallo, R.C.; et al. Emerging SARS-CoV-2 mutation hot spots include a novel RNA-dependent-RNA polymerase variant. J. Transl. Med. 2020, 18, 1-9. [CrossRef]

110. SARS-CoV-2 Mink-Associated Variant Strain—Denmark. Available online: https://www.who.int/csr/don/06-november-2020 -mink-associated-sars-cov2-denmark/en/ (accessed on 24 February 2021).

111. ECDC. Detection of New SARS-CoV-2 Variants Related to Mink. Available online: https://www.ecdc.europa.eu/sites/default/ files / documents / RRA-SARS-CoV-2-in-mink-12-nov-2020.pdf (accessed on 24 February 2021).

112. Rambaut, A.; Loman, N.; Pybus, O.; Barclay, W.; Barrett, J.; Carabelli, A.; Connor, T.; Peacock, T.; Robertson, D.L.; Volz, E.; et al. Preliminary Genomic Characterisation of an Emergent SARS-CoV-2 LINEAGE in the UK Defined by a Novel Set of Spike Mutations. Available online: https://virological.org/t/preliminary-genomic-characterisation-of-an-emergent-sars-cov-2lineage-in-the-uk-defined-by-a-novel-set-of-spike-mutations/563 (accessed on 24 February 2021).

113. Starr, T.N.; Greaney, A.J.; Hilton, S.K.; Ellis, D.; Crawford, K.H.D.; Dingens, A.S.; Navarro, M.J.; Bowen, J.E.; Tortorici, M.A.; Walls, A.C.; et al. Deep Mutational Scanning of SARS-CoV-2 Receptor Binding Domain Reveals Constraints on Folding and ACE2 Binding. Cell 2020, 182, 1295-1310.e20. [CrossRef]

114. Gu, H.; Chen, Q.; Yang, G.; He, L.; Fan, H.; Deng, Y.-Q.; Wang, Y.; Teng, Y.; Zhao, Z.; Cui, Y.; et al. Adaptation of SARS-CoV-2 in BALB/c mice for testing vaccine efficacy. Science 2020, 369, 1603-1607. [CrossRef]

115. Tegally, H.; Wilkinson, E.; Giovanetti, M.; Iranzadeh, A.; Fonseca, V.; Giandhari, J.; Doolabh, D.; Pillay, S.; San, E.J.; Msomi, N.; et al. Emergence and rapid spread of a new severe acute respiratory syndrome-related coronavirus 2 (SARS-CoV-2) lineage with multiple spike mutations in South Africa. medRxiv 2020. [CrossRef]

116. Leung, K.; Shum, M.H.; Leung, G.M.; Lam, T.T.; Wu, J.T. Early transmissibility assessment of the N501Y mutant strains of SARS-CoV-2 in the United Kingdom, October to November 2020. Eurosurveillance 2021, 26, 2002106. [CrossRef] [PubMed]

117. Alam, I.; Radovanovic, A.; Incitti, R.; Kamau, A.A.; Alarawi, M.; Azhar, E.I.; Gojobori, T. CovMT: An interactive SARS-CoV-2 mutation tracker, with a focus on critical variants. Lancet Infect. Dis. 2021, 21, 602. [CrossRef]

118. Computational Bioscience Research Center at the King Abdullah University of Science and Technology. COVID-19 Virus Mutation Tracker. Available online: https:/ / www.cbrc.kaust.edu.sa/covmt/index.php?p=home (accessed on 7 July 2021).

119. Cao, X. COVID-19: Immunopathology and its implications for therapy. Nat. Rev. Immunol. 2020, 20, 269-270. [CrossRef]

120. Xu, Z.; Shi, L.; Wang, Y.; Zhang, J.; Huang, L.; Zhang, C.; Liu, S.; Zhao, P.; Liu, H.; Zhu, L.; et al. Pathological findings of COVID-19 associated with acute respiratory distress syndrome. Lancet Respir. Med. 2020, 8, 420-422. [CrossRef]

121. Williams, R. Immune Biomarkers Tied to Severe COVID-19: Study. Available online: https://www.the-scientist.com/newsopinion/immune-biomarkers-tied-to-severe-covid-19-study-67843 (accessed on 7 July 2021).

122. What You Need to Know about Infectious Disease; The National Academies Press: Washington, DC, USA, 2011.

123. Luster, A.D.; Unkeless, J.C.; Ravetch, J.V. $\gamma$-Interferon transcriptionally regulates an early-response gene containing homology to platelet proteins. Nature 1985, 315, 672-676. [CrossRef] [PubMed]

124. Kheradmand, F.; Corry, D.B. CHEMOKINES, CXC I CXCL10 (IP-10). In Encyclopedia of Respiratory Medicine; Academic Press: Houston, TX, USA, 2006; pp. 402-407.

125. Channappanavar, R.; Fehr, A.R.; Vijay, R.; Mack, M.; Zhao, J.; Meyerholz, D.K.; Perlman, S. Dysregulated Type I Interferon and Inflammatory Monocyte-Macrophage Responses Cause Lethal Pneumonia in SARS-CoV-Infected Mice. Cell Host Microbe 2016, 19, 181-193. [CrossRef] [PubMed]

126. Channappanavar, R.; Fehr, A.R.; Zheng, J.; Wohlford-Lenane, C.; Abrahante, J.E.; Mack, M.; Sompallae, R.; McCray, P.B.; Meyerholz, D.K.; Perlman, S. IFN-I response timing relative to virus replication determines MERS coronavirus infection outcomes. J. Clin. Investig. 2019, 129, 3625-3639. [CrossRef]

127. Huang, K.-J.; Su, I.-J.; Theron, M.; Wu, Y.-C.; Lai, S.-K.; Liu, C.-C.; Lei, H.-Y. An Interferon-g-Related Cytokine Storm in SARS Patients. J. Med. Virol. 2005, 75, 185-194. [CrossRef] 
128. Shin, H.-S.; Kim, Y.; Kim, G.; Lee, J.Y.; Jeong, I.; Joh, J.-S.; Kim, H.; Chang, E.; Sim, S.Y.; Park, J.-S.; et al. Immune Responses to Middle East Respiratory Syndrome Coronavirus During the Acute and Convalescent Phases of Human Infection. Clin. Infect. Dis. 2018, 68, 984-992. [CrossRef]

129. Wong, C.K.; Lam, C.W.K.; Wu, A.K.L.; Ip, W.K.; Lee, N.; Chan, I.H.S.; Lit, L.C.W.; Hui, D.; Chan, M.H.M.; Chung, S.S.C.; et al. Plasma inflammatory cytokines and chemokines in severe acute respiratory syndrome. Clin. Exp. Immunol. 2004, 136, 95-103. [CrossRef] [PubMed]

130. NCBI. IL7 Interleukin 7 [Homo Sapiens (Human)]. Available online: https:/ / www.ncbi.nlm.nih.gov/gene? Db=gene\&Cmd= ShowDetailView\&TermToSearch=3574 (accessed on 27 January 2021).

131. NCBI. CCL3 C-C Motif Chemokine Ligand 3 [Homo Sapiens (Human)]. Available online: https://www.ncbi.nlm.nih.gov/gene/ 6348 (accessed on 27 January 2021).

132. Wadman, J.C.-F.E.; Kaiser, J.; Matacic, C. How Does Coronavirus Kill? Clinicians Trace a Ferocious Rampage Through the Body, from Brain to Toes. Available online: https://www.sciencemag.org/news/2020/04/how-does-coronavirus-kill-clinicians-traceferocious-rampage-through-body-brain-toes (accessed on 28 January 2021).

133. Laing, A.G.; Lorenc, A.; Barrio, I.D.M.D.; Das, A.; Fish, M.; Monin, L.; Muñoz-Ruiz, M.; McKenzie, D.R.; Hayday, T.; FrancosQuijorna, I.; et al. A dynamic COVID-19 immune signature includes associations with poor prognosis. Nat. Med. 2020, 26, 1623-1635. [CrossRef]

134. Shen, C.; Wang, Z.; Zhao, F.; Yang, Y.; Li, J.; Yuan, J.; Wang, F.; Li, D.; Yang, M.; Xing, L.; et al. Treatment of 5 Critically Ill Patients With COVID-19 With Convalescent Plasma. JAMA 2020, 323, 1582. [CrossRef]

135. Huang, S.; Shen, C.; Xia, C.; Huang, X.; Fu, Y.; Tian, L. A Retrospective Study on the Effects of Convalescent Plasma Therapy in 24 Patients Diagnosed with COVID-19 Pneumonia in February and March 2020 at 2 Centers in Wuhan, China. Med. Sci. Monit. 2020, 27, e928755. [CrossRef]

136. Abani, O.; Abbas, A.; Abbas, F.; Abbas, M.; Abbasi, S.; Abbass, H.; Abbott, A.; Abdallah, N.; Abdelaziz, A.; Abdelfattah, M.; et al. Convalescent plasma in patients admitted to hospital with COVID-19 (RECOVERY): A randomised controlled, open-label, platform trial. Lancet 2021, 397, 2049-2059. [CrossRef]

137. ClinicalTrials.gov. Views of COVID-19 Studies Listed on ClinicalTrials.gov (Beta). Available online: https://clinicaltrials.gov/ct2 / covid_view (accessed on 28 January 2021).

138. ClinicalTrials.gov. COVID-19 Studies from the World Health Organization Database. Available online: https://clinicaltrials.gov / ct2/who_table (accessed on 28 January 2021).

139. Beigel, J.H.; Tomashek, K.M.; Dodd, L.E.; Mehta, A.K.; Zingman, B.S.; Kalil, A.C.; Hohmann, E.; Chu, H.Y.; Luetkemeyer, A.; Kline, S.; et al. Remdesivir for the Treatment of Covid-19_Final Report. N. Engl. J. Med. 2020, 383, 1813-1836. [CrossRef] [PubMed]

140. Hojyo, S.; Uchida, M.; Tanaka, K.; Hasebe, R.; Tanaka, Y.; Murakami, M.; Hirano, T. How COVID-19 induces cytokine storm with high mortality. Inflamm. Regen. 2020, 40,1-7. [CrossRef]

141. Sanchez, G.A.M.; Reinhardt, A.; Ramsey, S.; Wittkowski, H.; Hashkes, P.J.; Berkun, Y. JAK1/2 inhibition with baricitinib in the treatment of autoinflammatory interferonopathies. J. Clin. Investig. 2018, 128, 3041-3052. [CrossRef]

142. Coronavirus (COVID-19) Update: FDA Authorizes Drug Combination for Treatment of COVID-19. Available online: https: / / www.fda.gov / news-events / press-announcements / coronavirus-covid-19-update-fda-authorizes-drug-combinationtreatment-covid-19 (accessed on 7 July 2021).

143. Kalil, A.C.; Patterson, T.F.; Mehta, A.K.; Tomashek, K.M.; Wolfe, C.R.; Ghazaryan, V.; Marconi, V.C.; Ruiz-Palacios, G.M.; Hsieh, L.; Kline, S.; et al. Baricitinib plus Remdesivir for Hospitalized Adults with Covid-19. N. Engl. J. Med. 2021, 384, 795-807. [CrossRef] [PubMed]

144. Report of the WHO-China Joint Mission on Coronavirus Disease 2019 (COVID-19). Available online: https: / / www.who.int/ publications/i/item/report-of-the-who-china-joint-mission-on-coronavirus-disease-2019-(covid-19) (accessed on 28 January 2021).

145. Ball, P. The lightning-fast quest for COVID vaccines-and what it means for other diseases. Nature 2020, 589, 16-18. [CrossRef]

146. Van Riel, D.; De Wit, E. Next-generation vaccine platforms for COVID-19. Nat. Mater. 2020, 19, 810-812. [CrossRef] [PubMed]

147. WHO. Status of COVID-19 Vaccines within WHO EUL/PQ Evaluation Process; WHO: Geneva, Switzerland, 2021.

148. Silveira, M.M.; Moreira, G.M.S.G.; Mendonça, M. DNA vaccines against COVID-19: Perspectives and challenges. Life Sci. 2020, 267, 118919. [CrossRef] [PubMed]

149. Marzi, A.; Ebihara, H.; Callison, J.; Groseth, A.; Williams, K.J.; Geisbert, T.W.; Feldmann, H. Vesicular Stomatitis Virus-Based Ebola Vaccines With Improved Cross-Protective Efficacy. J. Infect. Dis. 2011, 204, S1066-S1074. [CrossRef]

150. Suder, E.; Furuyama, W.; Feldmann, H.; Marzi, A.; De Wit, E. The vesicular stomatitis virus-based Ebola virus vaccine: From concept to clinical trials. Hum. Vaccines Immunother. 2018, 14, 2107-2113. [CrossRef] [PubMed]

151. Draft Landscape and Tracker of COVID-19 Candidate Vaccines; WHO: Geneva, Switzerland, 2021.

152. Malone, R.W.; Felgner, P.L.; Verma, I.M. Cationic liposome-mediated RNA transfection. Proc. Natl. Acad. Sci. USA 1989, 86, 6077-6081. [CrossRef]

153. Verbeke, R.; Lentacker, I.; De Smedt, S.C.; Dewitte, H. Three decades of messenger RNA vaccine development. Nano Today 2019, 28, 100766. [CrossRef]

154. Shih, H.-I.; Wu, C.-J.; Tu, Y.-F.; Chi, C.-Y. Fighting COVID-19: A quick review of diagnoses, therapies, and vaccines. Biomed. J. 2020, 43, 341-354. [CrossRef] 
155. U.S. Food and Drug Administration. Moderna COVID-19 Vaccine. Available online: https://www.fda.gov/emergencypreparedness-and-response/coronavirus-disease-2019-covid-19/moderna-covid-19-vaccine (accessed on 15 February 2021).

156. U.S. Food and Drug Administration. Pfizer-BioNTech COVID-19 Vaccine. Available online: https://www.fda.gov/emergencypreparedness-and-response/coronavirus-disease-2019-covid-19/pfizer-biontech-covid-19-vaccine (accessed on 15 February 2021).

157. Sahin, U.; Muik, A.; Vogler, I.; Derhovanessian, E.; Kranz, L.M.; Vormehr, M.; Quandt, J.; Bidmon, N.; Ulges, A.; Baum, A.; et al. BNT162b2 induces SARS-CoV-2-neutralising antibodies and T cells in humans. medRxiv 2020. preprint. [CrossRef]

158. Walsh, E.E.; Frenck, R.W.; Falsey, A.R.; Kitchin, N.; Absalon, J.; Gurtman, A.; Lockhart, S.; Neuzil, K.; Mulligan, M.J.; Bailey, R.; et al. Safety and Immunogenicity of Two RNA-Based Covid-19 Vaccine Candidates. N. Engl. J. Med. 2020, 383, 2439-2450. [CrossRef] [PubMed]

159. Polack, F.P.; Thomas, S.J.; Kitchin, N.; Absalon, J.; Gurtman, A.; Lockhart, S.; Perez, J.L.; Marc, G.P.; Moreira, E.D.; Zerbini, C.; et al. Safety and Efficacy of the BNT162b2 mRNA Covid-19 Vaccine. N. Engl. J. Med. 2020, 383, 2603-2615. [CrossRef] [PubMed]

160. Pfizer. Pfizer and BioNTech Announce Publication of Results from Landmark Phase 3 Trial of BNT162b2 COVID-19 Vaccine Candidate in The New England Journal of Medicine. Available online: https:/ / www.pfizer.com/news/press-release/pressrelease-detail/pfizer-and-biontech-announce-publication-results-landmark (accessed on 15 February 2021).

161. Moderna. Moderna's COVID-19 Vaccine Candidate Meets Its Primary Efficacy Endpoint in the First Interim Analysis of the Phase 3 COVE Study. Available online: https://investors.modernatx.com/news-releases/news-release-details/modernas-covid-19 -vaccine-candidate-meets-its-primary-efficacy (accessed on 15 February 2021).

162. Corbett, K.S.; Edwards, D.; Leist, S.R.; Abiona, O.M.; Boyoglu-Barnum, S.; Gillespie, R.A.; Himansu, S.; Schafer, A.; Ziwawo, C.T.; DiPiazza, A.T.; et al. SARS-CoV-2 mRNA Vaccine Development Enabled by Prototype Pathogen Preparedness. bioRxiv 2020. preprint. [CrossRef]

163. Corbett, K.S.; Flynn, B.; Foulds, K.E.; Francica, J.R.; Boyoglu-Barnum, S.; Werner, A.P.; Flach, B.; O'Connell, S.; Bock, K.W.; Minai, M.; et al. Evaluation of the mRNA-1273 Vaccine against SARS-CoV-2 in Nonhuman Primates. N. Engl. J. Med. 2020, 383, 1544-1555. [CrossRef] [PubMed]

164. Baden, L.R.; El Sahly, H.M.; Essink, B.; Kotloff, K.; Frey, S.; Novak, R.; Diemert, D.; Spector, S.A.; Rouphael, N.; Creech, C.B.; et al. Efficacy and Safety of the mRNA-1273 SARS-CoV-2 Vaccine. N. Engl. J. Med. 2021, 384, 403-416. [CrossRef]

165. Voysey, M.; Clemens, S.A.C.; Madhi, S.A.; Weckx, L.Y.; Folegatti, P.M.; Aley, P.K.; Angus, B.; Baillie, V.L.; Barnabas, S.L.; Bhorat, Q.E.; et al. Safety and efficacy of the ChAdOx1 nCoV-19 vaccine (AZD1222) against SARS-CoV-2: An interim analysis of four randomised controlled trials in Brazil, South Africa, and the UK. Lancet 2020, 397, 99-111. [CrossRef]

166. Van Doremalen, N.; Lambe, T.; Spencer, A.; Belij-Rammerstorfer, S.; Purushotham, J.N.; Port, J.R.; Avanzato, V.A.; Bushmaker, T.; Flaxman, A.; Ulaszewska, M.; et al. ChAdOx1 nCoV-19 vaccine prevents SARS-CoV-2 pneumonia in rhesus macaques. Nature 2020, 586, 1-8. [CrossRef]

167. Van Doremalen, N.; Haddock, E.; Feldmann, F.; Meade-White, K.; Bushmaker, T.; Fischer, R.J.; Okumura, A.; Hanley, P.W.; Saturday, G.; Edwards, N.J.; et al. A single dose of ChAdOx1 MERS provides protective immunity in rhesus macaques. Sci. Adv. 2020, 6, eaba8399, Corrected in 2021, 590, E24. [CrossRef]

168. Knoll, M.D.; Wonodi, C. Oxford-AstraZeneca COVID-19 vaccine efficacy. Lancet 2020, 397, 72-74. [CrossRef]

169. Fulker, J. New Collaboration Makes further 100 Million Doses of COVID-19 Vaccine Available to Low- and Middle-Income Countries. Available online: https:/ / www.gavi.org/news/media-room/new-collaboration-makes-further-100-million-dosescovid-19-vaccine-available-low\#: \{\}:text=Through\%20the\%20avid\%20support\%20of,Serum\%20Institute\%20of\%20India\%20 \%E2\%80\%9CAt (accessed on 15 February 2021).

170. International, A. COVID-19: Oxford/AstraZeneca Vaccine a Boost for Global Access, But Huge Inequality Remains. Available online: https: / / www.amnesty.org/en/latest/news/2020/11/oxford-astrazeneca-vaccine-a-boost-for-global-access-but-hugeinequality-remains / (accessed on 15 February 2021).

171. Inquiries, W.M. WHO Lists Two Additional COVID-19 Vaccines for Emergency Use and COVAX Roll-Out. Available online: https: / / www.who.int/news/item/15-02-2021-who-lists-two-additional-covid-19-vaccines-for-emergency-use-and-covaxroll-out (accessed on 17 March 2021).

172. AstraZeneca. Update on the Safety of COVID-19 Vaccine AstraZeneca. Available online: https:/ /www.astrazeneca.com/mediacentre/press-releases/2021/update-on-the-safety-of-covid-19-vaccine-astrazeneca.html (accessed on 17 March 2021).

173. WHO. WHO Statement on AstraZeneca COVID-19 Vaccine Safety Signals. Available online: https://www.who.int/news/item/ 17-03-2021-who-statement-on-astrazeneca-covid-19-vaccine-safety-signals (accessed on 17 March 2021).

174. Katz, M.H. How to Advise Persons Who Are Antibody Positive for SARS-CoV-2 about Future Infection Risk. JAMA Intern. Med. 2021, 181, 679. [CrossRef]

175. Doshi, P. Covid-19 vaccines: In the rush for regulatory approval, do we need more data? BMJ 2021, 373, n1244. [CrossRef] [PubMed]

176. Doshi, P. Covid-19 vaccine trial protocols released. BMJ 2020, 371, m4058. [CrossRef]

177. Doshi, P. Will covid-19 vaccines save lives? Current trials aren't designed to tell us. BMJ 2020, 371, m4037. [CrossRef] [PubMed]

178. Brown, C.M.; Vostok, J.; Johnson, H.; Burns, M.; Gharpure, R.; Sami, S.; Sabo, R.T.; Hall, N.; Foreman, A.; Schubert, P.L.; et al. Outbreak of SARS-CoV-2 Infections, Including COVID-19 Vaccine Breakthrough Infections, Associated with Large Public 
Gatherings-Barnstable County, Massachusetts, July 2021. MMWR Morb Mortal Wkly Rep. 2021, 70, 1059-1062. [CrossRef] [PubMed]

179. Thangaraj, J.W.V.; Yadav, P.; Kumar, C.G.; Shete, A.; Nyayanit, D.A.; Rani, D.S.; Kumar, A.; Kumar, M.S.; Sabarinathan, R.; Saravana Kumar, V. Predominance of Delta variant among the COVID-19 vaccinated and unvaccinated individuals, India, May 2021. J. Infect. 2021. [CrossRef]

180. Centers of Disease Control and Prevention. Interim Clinical Considerations for Use of COVID-19 Vaccines Currently Authorized in the United States. Available online: https:/ / www.cdc.gov/vaccines/covid-19/clinical-considerations/covid-19-vaccines-us.html (accessed on 14 August 2021).

181. University of Alabama at Birmingham, C.C.C. History of Radiation Oncology. Available online: https://en.wikipedia.org/wiki/ History_of_radiation_therapy (accessed on 18 January 2021).

182. Low-Dose Radiation Therapy. Available online: https://www.cancer.gov/publications/dictionaries/cancer-terms/def/lowdose-radiation-therapy (accessed on 8 January 2021).

183. Hanekamp, Y.N.; Giordano, J.; Hanekamp, J.C.; Khan, M.K.; Limper, M.; Venema, C.S.; Vergunst, S.D.; Verhoeff, J.J.C.; Calabrese, E.J. Immunomodulation Through Low-Dose Radiation for Severe COVID-19: Lessons From the Past and New Developments. Dose-Response 2020, 18, 1559325820956800. [CrossRef]

184. Arenas, M.; Sabater, S.; Hernández, V.; Rovirosa, A.; Lara, P.; Biete, A.; Panes, J. Anti-inflammatory effects of low-dose radiotherapy. Strahlenther. Onkol. 2012, 188, 975-981. [CrossRef]

185. Musser, J.; Edsall, D. A study of metabolism in leukaemia, under the influence of the X-ray. AAP 1905, 20, $294-323$.

186. Heidenhain, L.; Fried, C. Rontgenstrahlen und Entzundung (Roentgen irradiation in inflammation). Klin. Wochenschr. 1924, 3 , 1121-1122. [CrossRef]

187. Metcalfe, P.E. Low dose radiation therapy for COVID-19 pneumonia: Brief review of the evidence. Phys. Eng. Sci. Med. 2020, 43, 763. [CrossRef]

188. Powell, E. Radiation therapy of lobar pneumonia. Tex. State J. Med. 1936, 32, 237-240.

189. Scott, W.R. X-ray Therapy in the Treatment of Acute Pneumonia. Radiology 1939, 33, 331-349. [CrossRef]

190. Rousseau, J.P.; Johnson, W.M.; Harrell, G.T. The Value of Roentgen Therapy in Pneumonia Which Fails to Respond to the Sulfonamides. Radiology 1942, 38, 281-289. [CrossRef]

191. Oppenheimer, A. Roentgen therapy of "virus" pneumonia. Am. J. Roentgenol. Rad. Ther. 1943, 6, 635-638.

192. Koukourakis, M.I. Low-Dose Radiotherapy for Late-Stage COVID-19 Pneumonia? Dose Response 2020, 18. [CrossRef]

193. Edsall, D.L.; Pemberton, R. The use of the X-rays in unresolved pneumonia. Am. J. Med. Sci. 1907, 133, 286-296. [CrossRef]

194. Quimby, A.Q.; Quimby, W.A. Unresolved pneumonia: Successful treatment by roentgen ray. N. Y. Med. J. 1916, 103, 681-683.

195. Krost, G. Unresolved pneumonia in children. Treatment with roentgen ray. Am. J. Dis. Child. 1925, 30, 57-71. [CrossRef]

196. Merritt, E.A.; McPeak, E.M. Roentgen irradiation in unresolved pneumonia. Am. J. Roentgenol. 1930, 23 , 45-48.

197. Powell, E. Roentgen therapy of lobar pneumonia. J. Am. Med. Assoc. 1938, 110, 19-22. [CrossRef]

198. Powell, E. The treatment of acute pneumonias with roentgen rays. Am. J. Roentgenol. Rad. Ther. 1939, 41, 404-414.

199. Oppenheimer, A. Roentgen therapy of interstitial pneumonia. J. Pediatr. 1943, 23, 534-538. [CrossRef]

200. Gibson, P.G.; Qin, L.; Puah, S.H. COVID-19 acute respiratory distress syndrome (ARDS): Clinical features and differences from typical pre-COVID-19 ARDS. Med. J. Aust. 2020, 213, 54-56.e1. [CrossRef] [PubMed]

201. Prasanna, P.G.; Woloschak, G.E.; DiCarlo, A.L.; Buchsbaum, J.C.; Schaue, D.; Chakravarti, A.; Cucinotta, F.A.; Formenti, S.C.; Guha, C.; Hu, D.J.; et al. Low-Dose Radiation Therapy (LDRT) for COVID-19: Benefits or Risks? Radiat. Res. 2020, 194, 452-464. [CrossRef]

202. Azzam, E.I.; Jay-Gerin, J.-P.; Pain, D. Ionizing radiation-induced metabolic oxidative stress and prolonged cell injury. Cancer Lett. 2012, 327, 48-60. [CrossRef]

203. Schaue, D.; McBride, W.H. Flying by the seat of our pants: Is low dose radiation therapy for COVID-19 an option? Int. J. Radiat. Biol. 2020, 96, 1219-1223. [CrossRef] [PubMed]

204. Candas, D.; Fan, M.; Nantajit, D.; Vaughan, A.T.; Murley, J.S.; Woloschak, G.E.; Grdina, D.J.; Li, J.J. CyclinB1/Cdk1 phosphorylates mitochondrial antioxidant MnSOD in cell adaptive response to radiation stress. J. Mol. Cell Biol. 2012, 5, 166-175. [CrossRef]

205. Eldridge, A.; Fan, M.; Woloschak, G.; Grdina, D.J.; Chromy, B.A.; Li, J.J. Manganese superoxide dismutase interacts with a large scale of cellular and mitochondrial proteins in low-dose radiation-induced adaptive radioprotection. Free. Radic. Biol. Med. 2012, 53, 1838-1847. [CrossRef]

206. Grdina, D.J.; Murley, J.S.; Miller, R.C.; Mauceri, H.J.; Sutton, H.G.; Thirman, M.J.; Li, J.J.; Woloschak, G.; Weichselbaum, R.R. A Manganese Superoxide Dismutase (SOD2)-Mediated Adaptive Response. Radiat. Res. 2013, 179, 115-124. [CrossRef]

207. Li, J.J. Mitigating Coronavirus-Induced Acute Respiratory Distress Syndrome by Radiotherapy. iScience 2020, $23,101215$. [CrossRef]

208. Kojima, S.; Ishida, H.; Takahashi, M.; Yamaoka, K. Elevation of glutathione induced by low-dose gamma rays and its involvement in increased natural killer activity. Radiat. Res. 2002, 157, 275-280. [CrossRef]

209. De Toledo, S.M.; Asaad, N.; Venkatachalam, P.; Li, L.; Howell, R.; Spitz, D.; Azzam, E.I. Adaptive Responses to Low-Dose/LowDose-Rate $\gamma$ Rays in Normal Human Fibroblasts: The Role of Growth Architecture and Oxidative Metabolism. Radiat. Res. 2006, 166, 849-857. [CrossRef] [PubMed] 
210. Nakatsukasa, H.; Tsukimoto, M.; Ohshima, Y.; Tago, F.; Masada, A.; Kojima, S. Suppressing Effect of Low-Dose Gamma-Ray Irradiation on Collagen-Induced Arthritis. J. Radiat. Res. 2008, 49, 381-389. [CrossRef] [PubMed]

211. Research Result. Available online: https://www.clinicaltrials.gov/ct2/home (accessed on 20 August 2021).

212. Hess, C.B.; Buchwald, Z.S.; Stokes, W.; Nasti, T.H.; Switchenko, J.M.; Weinberg, B.D.; Steinberg, J.P.; Godette, K.D.; Murphy, D.; Ahmed, R.; et al. Low-dose whole-lung radiation for COVID-19 pneumonia: Planned day 7 interim analysis of a registered clinical trial. Cancer 2020, 126, 5109-5113. [CrossRef]

213. Partners, F.A. Room Air. Medical Dictionary. 2009. Available online: Medical-dictionary.thefreedictionary.com (accessed on 2 March 2021).

214. Ameri, A.; Rahnama, N.; Bozorgmehr, R.; Mokhtari, M.; Farahbakhsh, M.; Nabavi, M.; Shoaei, S.D.; Izadi, H.; Kashi, A.S.Y.; Dehbaneh, H.S.; et al. Low-Dose Whole-Lung Irradiation for COVID-19 Pneumonia: Short Course Results. Int. J. Radiat. Oncol. 2020, 108, 1134-1139. [CrossRef]

215. Lara, P.C.; Burgos, J.; Macias, D. Low dose lung radiotherapy for COVID-19 pneumonia. The rationale for a cost-effective anti-inflammatory treatment. Clin. Transl. Radiat. Oncol. 2020, 23, 27-29. [CrossRef]

216. Hess, C.; Buchwald, Z.; Stokes, W.; Nasti, T.; Switchenko, J.; Weinberg, B.; Rouphael, N.; Steinberg, J.; Godette, K.; Murphy, D.; et al. Immunomodulatory Low-Dose Whole-Lung Radiation for Patients with COVID-19-Related Pneumonia. Int. J. Radiat. Oncol. 2020, 108, 1401. [CrossRef]

217. Sharma, D.N.; Guleria, R.; Wig, N.; Mohan, A.; Rath, G.K.; Subramani, V.; Bhatnagar, S.; Mallick, S.; Sharma, A. Low Dose Radiation Therapy for COVID-19 Pneumonia: A Pilot Study. medRxiv 2020. [CrossRef]

218. Papachristofilou, A.; Finazzi, T.; Blum, A.; Zehnder, T.; Zellweger, N.; Lustenberger, J.; Bauer, T.; Dott, C.; Avcu, Y.; Kohler, G.; et al. Low-Dose Radiation Therapy for Severe COVID-19 Pneumonia: A Randomized Double-Blind Study. Int. J. Radiat. Oncol. Biol. Phys. 2021, 110, 1274-1282. [CrossRef] [PubMed]

219. Moreno-Olmedo, E.; Suárez-Gironzini, V.; Pérez, M.; Filigheddu, T.; Mínguez, C.; Sanjuan-Sanjuan, A.; González, J.A.; Rivas, D.; Gorospe, L.; Larrea, L.; et al. COVID-19 pneumonia treated with ultra-low doses of radiotherapy (ULTRA-COVID study): A single institution report of two cases. Strahlenther. Onkol. 2021, 197, 429-437. [CrossRef] [PubMed]

220. Ameri, A.; Ameri, P.; Rahnama, N.; Mokhtari, M.; Sedaghat, M.; Hadavand, F.; Bozorgmehr, R.; Haghighi, M.; Taghizadeh-Hesary, F. Low-Dose Whole-Lung Irradiation for COVID-19 Pneumonia: Final Results of a Pilot Study. Int. J. Radiat. Oncol. 2020, 109, 859-866. [CrossRef] [PubMed]

221. Anti-inflammatory Effect of Low-Dose Whole-Lung Radiation for COVID-19 Pneumonia; 9 February 2021. Available online: https: / / clinicaltrials.gov/ct2/show/study /NCT04534790 (accessed on 21 August 2021).

222. Inhalation Low Dose Radionuclide Therapy in Treatment COVID-19. Available online: https://clinicaltrials.gov/ct2/show/ NCT04724538?term=NCT04724538\&draw=2\&rank=1 (accessed on 21 March 2021).

223. Best Supportive Care With or Without Low Dose Whole Lung Radiation Therapy for the Treatment of COVID-19 (RESCUE1-19). Available online: https: / clinicaltrials.gov / ct2/ show / NCT04433949?term=NCT04433949\&draw=2\&rank=1 (accessed on 21 March 2021).

224. Low Dose Pulmonary Irradiation in Patients with COVID-19 Infection of Bad Prognosis (COVRTE-19). Available online: https: / / clinicaltrials.gov/ct2/ show / NCT04414293?term=NCT04414293\&draw=2\&rank=1 (accessed on 21 March 2021).

225. Low Dose Whole Lung Radiation Therapy for Patients with COVID-19 and Respiratory Compromise (VENTED). Available online: https:/ / clinicaltrials.gov/ct2/ show / NCT04427566?term=NCT04427566\&draw=2\&rank=1 (accessed on 21 March 2021).

226. Low-Dose Radiotherapy for Patients with SARS-COV-2 (COVID-19) Pneumonia (PREVENT). Available online: https:// clinicaltrials.gov / ct2/ show / NCT04466683?term=NCT04466683\&draw=2\&rank=1 (accessed on 21 March 2021).

227. Lung Irradiation for COVID-19 Pneumonia. Available online: https:/ / clinicaltrials.gov/ct2/show / NCT04393948?term=NCT043 93948\&draw=2\&rank=1 (accessed on 21 March 2021).

228. Low Dose Whole Lung Radiotherapy for Older Patients with COVID-19 Pneumonitis. Available online: https: / / clinicaltrials. gov / ct2 / show / NCT04493294?term =NCT04493294\&draw=2\&rank=1 (accessed on 21 March 2021).

229. Hadjiyiannakis, D.; Dimitroyannis, D.; Eastlake, L.; Peedell, C.; Tripathi, L.; Simcock, R.; Vyas, A.; Deutsch, E.; Chalmers, A. Personal View: Low-Dose Lung Radiotherapy Should be Evaluated as a Treatment for Severe COVID-19 Lung Disease. Clin. Oncol. 2020, 33, e64-e68. [CrossRef]

230. Low Dose Lung Radiotherapy to Treat COVID-19 Pneumonia. Available online: https://clinicaltrials.gov/ct2/show/NCT04572 412? term $=$ NCT04572412\&draw=1\&rank=1 (accessed on 21 March 2021).

231. COVID-19 Pneumonitis Low Dose Lung Radiotherapy (COLOR-19) (COLOR-19). Available online: https://clinicaltrials.gov/ct2 / show / NCT04377477?term=NCT04377477\&draw=2\&rank=1 (accessed on 21 March 2021).

232. Low Dose Radiotherapy for COVID-19 Pneumonitis (LOWRAD-Cov19). Available online: https://clinicaltrials.gov / ct2/show / NCT04420390?term $=$ NCT04420390\&draw=2\&rank=1 (accessed on 21 March 2021).

233. Algara, M.; Arenas, M.; Marin, J.; Vallverdu, I.; Fernandez-Letón, P.; Villar, J.; Fabrer, G.; Rubio, C.; Montero, A. Low dose anti-inflammatory radiotherapy for the treatment of pneumonia by covid-19: A proposal for a multi-centric prospective trial. Clin. Transl. Radiat. Oncol. 2020, 24, 29-33. [CrossRef]

234. Low Dose Anti-inflammatory Radiotherapy for the Treatment of Pneumonia by COVID-19. Available online: https: / clinicaltrials. gov/ct2/show / NCT04380818?term=NCT04380818\&draw=2\&rank=1 (accessed on 21 March 2021). 
235. Low-Dose Radiation Therapy to Lungs in Moderate COVID-19 Pneumonitis: A Case-Control Pilot Study (LOCORAD). Available online: https:/ / clinicaltrials.gov/ct2/show/NCT04904783\#contacts (accessed on 20 August 2021).

236. Spitz, D.R.; Azzam, E.I.; Li, J.J.; Gius, D. Metabolic oxidation/reduction reactions and cellular responses to ionizing radiation: A unifying concept in stress response biology. Cancer Metastasis Rev. 2004, 23, 311-322. [CrossRef]

237. Vaiserman, A.; Koliada, A.; Zabuga, O.; Socol, Y. Health Impacts of Low-Dose Ionizing Radiation: Current Scientific Debates and Regulatory Issues. Dose-Response 2018, 16, 1559325818796331. [CrossRef] [PubMed]

238. Brooks, A.L. Paradigm Shifts in Radiation Biology: Their Impact on Intervention for Radiation-Induced Disease. Radiat. Res. 2005, 164, 454-461. [CrossRef]

239. Paunesku, T.; Haley, B.; Brooks, A.; Woloschak, G.E. Biological basis of radiation protection needs rejuvenation. Int. J. Radiat. Biol. 2017, 93, 1056-1063. [CrossRef] [PubMed]

240. Pandey, B.N.; Gordon, D.M.; De Toledo, S.M.; Pain, D.; Azzam, E.I. Normal Human Fibroblasts Exposed to High- or Low-Dose Ionizing Radiation: Differential Effects on Mitochondrial Protein Import and Membrane Potential. Antioxid. Redox Signal. 2006, 8, 1253-1261. [CrossRef]

241. Zhang, J.; De Toledo, S.M.; Pandey, B.N.; Guo, G.; Pain, D.; Li, H.; Azzam, E.I. Role of the translationally controlled tumor protein in DNA damage sensing and repair. Proc. Natl. Acad. Sci. USA 2012, 109, E926-E933. [CrossRef] [PubMed]

242. Mortazavi, S.M.J.; Kefayat, A.; Cai, J. Low-dose radiation as a treatment for COVID-19 pneumonia: A threat or real opportunity? Med. Phys. 2020, 47, 3773-3776. [CrossRef]

243. Gonzalez, A.J. Biological effects of low doses of ionizing radiation: A fuller picture. IAEA Bull. 1994, 4, 37-45.

244. The Nobel Prize in Chemistry. Available online: https:/ / www.nobelprize.org (accessed on 21 March 2021).

245. Healthcare, S. Holy Name Medical Center in Teaneck, New Jersey Acquires Sensus Healthcare's Low-dose Radiation Therapy System to Treat Pneumonia in COVID-19 Patients. Available online: https:/ /www.sensushealthcare.com/holy-name-medicalcenter-in-teaneck-new-jersey-acquires-sensus-healthcares-low-dose-radiation-therapy-system-to-treat-pneumonia-in-covid19-patients / (accessed on 2 February 2021).

246. Deloch, L.; Fuchs, J.; Rückert, M.; Fietkau, R.; Frey, B.; Gaipl, U.S. Low-Dose Irradiation Differentially Impacts Macrophage Phenotype in Dependence of Fibroblast-Like Synoviocytes and Radiation Dose. J. Immunol. Res. 2019, 2019, 1-11. [CrossRef]

247. Horby, P.; Lim, W.S.; Emberson, J.R.; Mafham, M.; Bell, J.L.; Linsell, L.; Staplin, N.; Brightling, C.; Ustianowski, A.; Elmahi, E.; et al. Dexamethasone in Hospitalized Patients with Covid-19_Preliminary Report. N. Engl. J. Med. 2020. [CrossRef]

248. Pandey, B.N. Low-dose radiation therapy for coronavirus disease-2019 pneumonia: Is it time to look beyond apprehensions? Ann. Thorac. Med. 2020, 15, 199-207. [CrossRef] [PubMed] 